\title{
Panoptic View of Prognostic Models for Personalized Breast Cancer Management
}

\author{
Geetanjali Saini ${ }^{1}$, Karuna Mittal ${ }^{1}$, Padmashree Rida ${ }^{1}$, Emiel A. M. Janssen ${ }^{2}$, Keerthi Gogineni ${ }^{3}$ \\ and Ritu Aneja ${ }^{1, *}$ \\ 1 Department of Biology, Georgia State University, Atlanta, GA 30303, USA \\ 2 Department of Pathology, Stavanger University Hospital, 4011 Stavanger, Norway \\ 3 Department of Hematology and Medical Oncology, Emory University School of Medicine; \\ Atlanta, GA 30322, USA \\ * Correspondence: raneja@gsu.edu; Tel.: +1-404-413-5417; Fax: +1-404-413-5301
}

Received: 5 August 2019; Accepted: 5 September 2019; Published: 7 September 2019

\begin{abstract}
The efforts to personalize treatment for patients with breast cancer have led to a focus on the deeper characterization of genotypic and phenotypic heterogeneity among breast cancers. Traditional pathology utilizes microscopy to profile the morphologic features and organizational architecture of tumor tissue for predicting the course of disease, and is the first-line set of guiding tools for customizing treatment decision-making. Currently, clinicians use this information, combined with the disease stage, to predict patient prognosis to some extent. However, tumoral heterogeneity stubbornly persists among patient subgroups delineated by these clinicopathologic characteristics, as currently used methodologies in diagnostic pathology lack the capability to discern deeper genotypic and subtler phenotypic differences among individual patients. Recent advancements in molecular pathology, however, are poised to change this by joining forces with multiple-omics technologies (genomics, transcriptomics, epigenomics, proteomics, and metabolomics) that provide a wealth of data about the precise molecular complement of each patient's tumor. In addition, these technologies inform the drivers of disease aggressiveness, the determinants of therapeutic response, and new treatment targets in the individual patient. The tumor architecture information can be integrated with the knowledge of the detailed mutational, transcriptional, and proteomic phenotypes of cancer cells within individual tumors to derive a new level of biologic insight that enables powerful, data-driven patient stratification and customization of treatment for each patient, at each stage of the disease. This review summarizes the prognostic and predictive insights provided by commercially available gene expression-based tests and other multivariate or clinical -omics-based prognostic/predictive models currently under development, and proposes a more inclusive multiplatform approach to tackling the challenging heterogeneity of breast cancer to individualize its management. "The future is already here-it's just not very evenly distributed."-William Ford Gibson
\end{abstract}

Keywords: breast cancer; prognosis; prediction; liquid biopsy; immunohistochemistry; digital pathology; multigene assays

\section{Introduction}

It has become increasingly apparent over the past few decades that in order to grasp and effectively combat the heterogeneity that typifies breast cancer (BC), high-granularity tumor biomarker profiling is not merely desirable, but in fact, indispensable. Increasingly affordable novel technologies and deep-content analytics are enabling molecular profiling of tumors throughout the course of patient care. Specifically, the interrogation of the tumor tissue as well as its genome, transcriptome, epigenome, proteome, metabolome, and other aspects of both the tumor and the host characterize the burgeoning 
field of -omics research, which uses bioinformatics and computational technology to explore the mechanistic properties of molecules. The discovery and validation of definitive genetic and phenotypic biomarkers have emerged as the cornerstone of predictive and prognostic testing that can be used to parse patients with BC into subgroups and risk categories for analysis, thus helping to identify targeted treatments for each patient's unique molecular profile by "matching the pill to the ill."

Molecular diagnostic tests, however, are only as good as the biomarkers they identify or measure. Like any diagnostic test, a tumor biomarker test, whether genetic or phenotypic, must have analytic and clinical validity as well as clinical utility. In the current BC landscape, several commercial genomic assays available to oncologists are transforming patient treatment. The assays to determine the status of the biomarkers such as estrogen receptor (ER), progesterone receptor (PR), and human epidermal growth factor receptor 2 (HER2) have long been used for the primary identification of tumors for targeted therapy and prognostication. Other assays serve as companion diagnostic (CDx) tests due to their ability to predict tumor response to specific cancer therapy drugs. These CDx assays are useful for existing as well as new drugs, increasing the clinical value of therapy by selecting for potential responders or excluding patients at risk for severe adverse effects. For pharmaceutical companies, CDx assays facilitate regulatory approval of new therapeutic regimens, enhance the probability of success in clinical trials, and in combination with adaptive trial designs, make trials more cost-effective.

Clinical decision making in BC chiefly relies on determining clinicopathologic features of a tumor as well as on protein- and gene-based biomarker panels. The review, ordered in a broadly chronological fashion, begins with examining these mainstays and developments therein. This is followed by a discussion on more recent technologies for data gleaning (liquid biopsies, tumor microenvironment-based markers and metabolomics) that are receiving tremendous attention in consonance with the significant information they generate. The advances in digital pathology, particularly the use of convoluted and deep neural networks, adding invaluable tools to the repertoire, have also been covered in the review. Figure 1 captures a comprehensive picture of the current and emergent approaches in clinical management of BC patients, which are discussed in the subsequent sections.

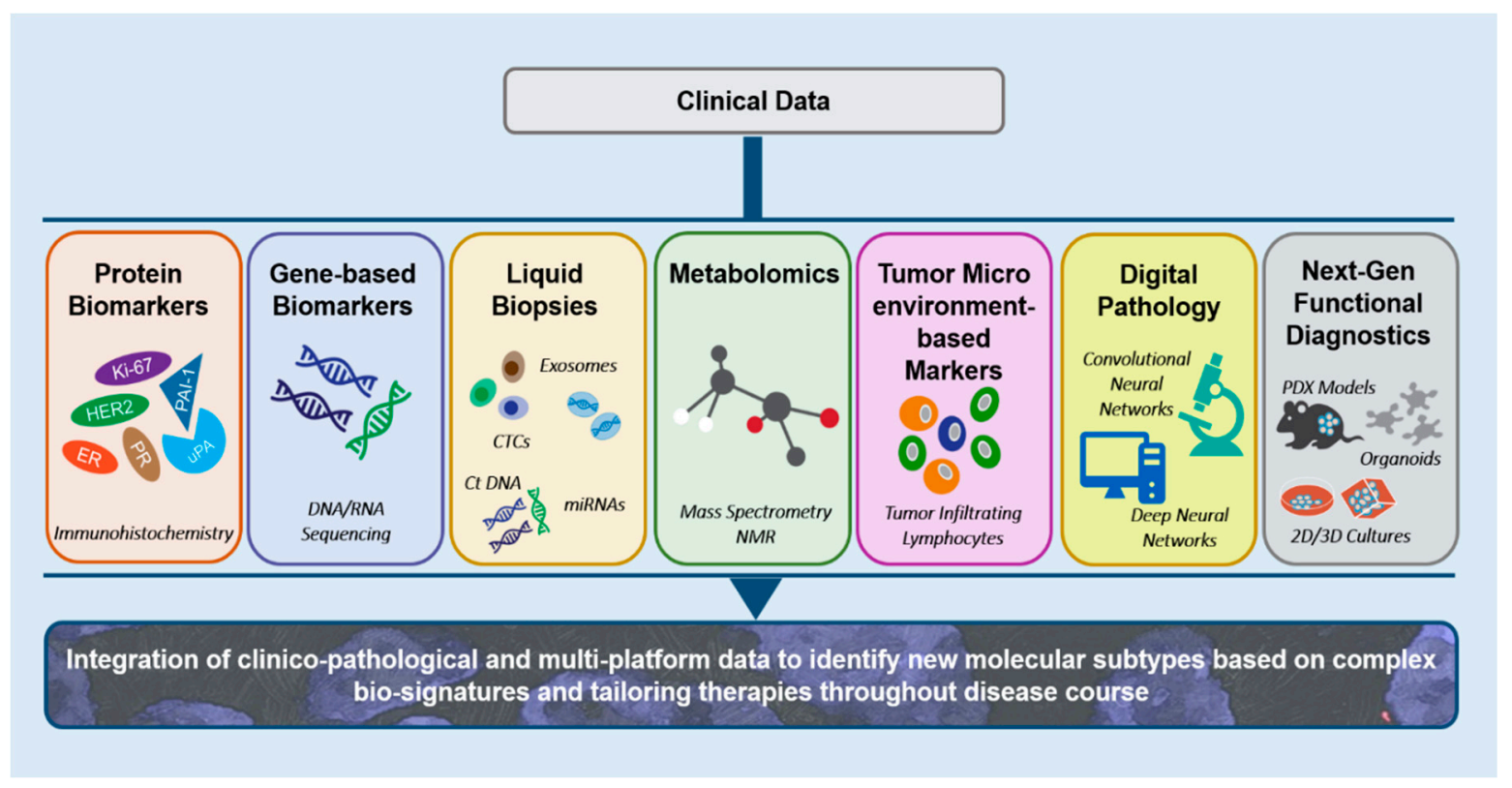

Figure 1. An overview of the various data generating hubs that allows integration of clinico-pathological and multi-omics data. This wealth of information can be meaningfully mined to identify new molecular subtypes based on complex multi-omics generated bio-signatures that can facilitate tailored therapies throughout the disease course in breast cancer patients. 


\section{Integrating Clinico-Pathological Variables to Frame Breast Cancer Prognostic Models}

The clinico-pathological parameters, typically the tumor size, grade, nodal status, age of patient are crucial variables that when combined meaningfully can effectively determine the prognosis in BC patients. In primary breast cancer, the Nottingham prognostic index (NPI) calculated using the tumor size, lymph-node stage, and pathological grade is considered the standard [1]. The Nottingham prognostic index plus (NPI+) is an improvement on this and is based on an initial determination of the biological class of the tumor combined with clinicopathologic prognostic variables. The NPI+ can predict the risk of metastases and is touted to provide enhanced risk stratification as well as predict long-term survival [2]. Kwon et al. have proposed a modified Nottingham prognostic index (MNPI) for stratifying patients with stage I to III of triple negative BC (TNBC), a notoriously aggressive type of $\mathrm{BC}$. The index incorporates information on the tumor size, $\mathrm{LN}$ status, and tumor grade according to a modified Scarff-Bloom-Richardson (MSBR) grade, and is potentially an important prognostic tool for patients with TNBC [3]. Given the highly heterogeneous nature of this BC subtype, and the existence of distinct molecular subtypes within TNBC, it is possible that prognostic models assigning appropriate weights to subtype-specific variables may need to be developed for the individual molecular subtypes of TNBC. The Van Nuys prognostic index (VNPI) is a scoring system (based on the tumor size, margin width, grade, comedonecrosis and age) that assists the treatment decision making in ductal carcinoma in situ patients (DCIS) [4]. In addition to these, several web-based prognostic tools derived from clinicopathologic variables, e.g., Adjuvant! Online, PREDICT, Clinical Treatment Score post -5 years (CTS5) are freely available and may provide adjunctive information in clinical decision making $[5,6]$. The clinicopathologic variables in harness with the gene and protein-based biomarkers can provide far superior and robust prognostication.

\section{Immunohistochemistry-Based Prognostic Assays for Breast Cancer}

The most widely used protein markers (ER, PR, HER2, Ki67) are well-described predictive markers for hormonal and anti-HER2 therapy. Immunohistochemistry (IHC) is a commonly used technique to measure the expression of these biomarkers. Additionally, in situ hybridization (e.g., fluorescence in situ hybridization and chromogenic in situ hybridization) is performed to quantify HER2 gene amplification which often results in HER2 overexpression. The IHC4 index is a non-commercial algorithm that assesses these four protein markers, generating a disease recurrence score. A lack of validation studies and poor reproducibility has marred this prognostic tool's prospects in general clinical application $[7,8]$. The IHC4 and CTS (a clinical treatment score based on clinico-pathological parameters), have been combined by Cuzick et al., to yield an overall prognostic score that may prove useful in predicting risk of recurrence in ER positive $\mathrm{BC}$ patients [7,9].

The urokinase plasminogen activator (uPA) and its inhibitor protein plasminogen activator inhibitor-1 (PAI-1) have shown to be promising independent prognostic markers and have attained the highest level of evidence (LOE-1a) in terms of clinical utility in BC [10,11]. In several European countries, the value of $\mathrm{UPA}$ and PAI- 1 as biomarkers for a predictive outcome in $\mathrm{LN}$-negative $\mathrm{BC}$ has been validated in both retrospective and prospective studies [11,12]. The high levels of these markers (measured by an American Society of Clinical Oncology [ASCO] recommended enzyme-linked immunosorbent assay [ELISA] based assay, using extracts of fresh or freshly frozen breast tumor tissue) correlate strongly with an adverse prognosis and increased benefits from adjuvant chemotherapy $[10,13,14]$. Compared with Oncotype Dx and MammaPrint, uPA/PAI-1 assessment is more convenient, cost-effective and may even provide greater prognostic and predictive value for $\mathrm{BC}$ outcomes [15-17]. Unfortunately, no validated assay for uPA/PAI-1 is currently available.

The multiplexed immunohistochemistry $(\mathrm{mIHC})$ is a recent tool that allows for simultaneous probing of several protein biomarkers on the same biological sample. The staining of samples can be chromogenic or fluorescent. This is crucial when the tumor sample size is limiting. The mIHC can provide valuable insights about the co-expression and spatial distribution of many targets without compromising tissue integrity [18]. Despite the fact that IHC-based assays do not require tissue 
microdissection and are more clinically facile, pre-analytic tissue processing can significantly impact test results [19]. Other studies have uncovered additional concerns with IHC-based assays, such as inconsistent performance of IHC reagents, antibodies and widespread variation in slide scoring, which can significantly influence test results and call into question the IHC platform's consistency and reliability [19].

\section{Gene-Centered Biomarkers: Translating Molecular Complexity of Tumors by Gene Expression-Based Assays}

Many currently available prognostic and predictive tests in breast oncology utilize genomic and gene expression-based biomarkers, a trend that was spurred by the continually decreasing costs of whole-genome, gene panel, and RNA sequencing, and that requires only small sample volumes for processing. Multigene assays often interrogate one or more pathways that drive tumor biology, and predict the natural progression of the disease (with or without therapeutic intervention) based on its inherent aggressiveness. Thus, these tests help distinguish patients who need more aggressive treatments from those for whom the current standard-of-care may suffice, reducing healthcare expenditures. Several multigene tests (MGTs) are now routinely used in the clinical setting, and have been described in previous literature [20-71]. The focus of this review is on more recent and emerging technologies, and these MGTs are summarized in Table 1 and their gene/protein signatures illustrated in Figure 2.

\begin{tabular}{|c|c|}
\hline Oncotype Dx and Oncotype DCIS & Prosigna \\
\hline \multirow{3}{*}{$\begin{array}{l}\text { Estrogen receptor: ESR1, PGR, BLC2, } \\
\text { SCUBE2 } \\
\text { Proliferation: Ki67, STK15, Survivin, } \\
\text { CCNB1, MYBL2 } \\
\text { Related: HER-2, GRB7, MMP11, CTSL2, } \\
\text { GSTM1, CD68, BACG1 } \\
\text { Reference Genes: ACTB, GAPDH, } \\
\text { RPLPO, GUS, TFRC } \\
\text { Proliferation: Ki67, STK15, Survivin, } \\
\text { CCNB1, MYBL2 } \\
\text { Hormone Receptor Group: PR, GSTM1 } \\
\text { Reference Genes: ACTB, GAPDH, } \\
\text { RPLPO, GUS, TFRC }\end{array}$} & $\begin{array}{l}\text { PGR, NAT1, BCL2, ESR1, MAPT, } \\
\text { MDM2, CXXC5, GPR160, FOXA1, } \\
\text { MLPH, SLC39A6, ACTR3B, BLVRA, } \\
\text { TMEM45B, CDH3, MMP11, SFRP1, } \\
\text { FOXC1, MIA, KRT14, MYC, BAG1, } \\
\text { ERBB2, GRB7, PHGDH, PTTG1, KRT5, } \\
\text { KRT17, UBE2C, CDC6, ANLN, ORC6L, } \\
\text { TYMS, BIRC5, CEP55, CENPF, CCNB1, } \\
\text { RRM2, MK167, CCNE1, KIF2C, CDC20, } \\
\text { UBE2T, MYBL2, EX2O1, MELK, EGFR, } \\
\text { FGFR4 }\end{array}$ \\
\hline & Breast Cancer Index \\
\hline & $\begin{array}{l}\text { BUB1B, CENPA, NEK2, RACGAP1, } \\
\text { RRM2 } \\
\text { HOXB13:IL17BR (H/I or MGI ratio) }\end{array}$ \\
\hline MammaPrint & EndoPredict \\
\hline \multirow{2}{*}{$\begin{array}{l}\text { ALOB005D, COMBIG63649RC, } \\
\text { LOC5120CJ, COMBIG45216RC, } \\
\text { COMBIG38288RC, AA555029RC, } \\
\text { CONBIG2655, 26552RC, FLT9, MMP9, } \\
\text { DC13, EXT1, AL137718, PK428, HEC, } \\
\text { ECT2, GMPS, CONBIG22185RC, UCH37, } \\
\text { CONBIG35251RC, DCK, CENPA, SM20, } \\
\text { MCM6, AKAP2, CONBIG5645, TRC, RFC4, } \\
\text { DKFZP584D062, SLC2A3, NP1, } \\
\text { CONBIG46831RC, CONBIG24252RC, } \\
\text { FLJ11180, CONBIG51464RC, IGFBPS, } \\
\text { IGFBPS } \\
\text { CCNE2, ESM1, COMBIG28217RC, DECI, } \\
\text { AP2B1, CFFM4, PEC1, TOFB3, } \\
\text { COMBIG45223RC, COMBIG55377RC, } \\
\text { HSA250830, GSTM3, BBC3, CEGP1, } \\
\text { COMBIG48328RC, WISP1, ALDH4, } \\
\text { KAA1442, CONBIG32125RC, FGF10 }\end{array}$} & $\begin{array}{l}\text { Cancer genes: BIRC5, UBE2C, DHCR7, } \\
\text { RBBP8, IL6ST, AZGP1, MGP, and STC2 } \\
\text { House keeping genes: CALM2, OAZ1, } \\
\text { and RPL37A }\end{array}$ \\
\hline & $\begin{array}{l}\text { SPBs: IL-6, IL-8, TNF- } \alpha, I N F-\gamma, C E A \text {, } \\
\text { ErbB2, OPN, HGF, FasL, VEGF-C, } \\
\text { VEGF-D } \\
\text { TaaBs: ALG10, ATF3, ATP6AP1, BAT4 } \\
\text { (GPANK1), BDNF, BMX, C15orf48 } \\
\text { (NMES1), CSNK1E, CTAG1A, CTAG2, } \\
\text { CTBP1, DBT, EIF3E, FRS3, GPR157, } \\
\text { HOXD1, IGFBP2, MUC1, MYOZ2, p53, } \\
\text { PDCD6IP, RAB5A, RAC3, SELL, } \\
\text { SERPINH1, SF3A1, SLC33A1, SOX2, } \\
\text { TFCP2, TRIM32, UBAP1, ZMYM6, } \\
\text { ZNF510 }\end{array}$ \\
\hline
\end{tabular}

Figure 2. Gene/protein signatures of the prognostic/predictive multigene tests for breast cancer. SPBs [Serum Protein Biomarkers]; TaaBs [Tumor-associated autoantibodies]. 
Table 1. Prognostic/predictive multigene tests routinely used in the clinical settings for breast cancer. FFPE/FPET [Formalin-fixed Paraffin-embedded].

\begin{tabular}{|c|c|c|c|c|c|c|c|}
\hline $\begin{array}{l}\text { MGT/IHC Assay and } \\
\text { Provider }\end{array}$ & $\begin{array}{c}\text { Tissue Type, } \\
\text { Technique, Facility }\end{array}$ & Endorsement & Clinical Indications & Prognostic/Predictive Value & Risk Groups/Stratification and Implications & $\begin{array}{c}\text { Trials and } \\
\text { Validation Studies }\end{array}$ & $\begin{array}{l}\text { Comparative } \\
\text { Advantage }\end{array}$ \\
\hline $\begin{array}{l}\text { Oncotype DX } \\
\text { Genomic Health } \\
\text { [20-41] }\end{array}$ & $\begin{array}{c}\text { FFPE, } \\
\text { qRT-PCR, } \\
\text { Centralized }\end{array}$ & $\begin{array}{l}\text { NCCN, } \\
\text { ASCO, } \\
\text { St Gallen }\end{array}$ & $\begin{array}{l}\text { ER+, } \\
\text { O-3 node+, } \\
\text { Stage III } \\
\text { invasive, } \\
\text { Treatment decision with } \\
\text { tamoxifen or aromatase } \\
\text { inhibitors }\end{array}$ & $\begin{array}{c}\text { Prognostic for distant recurrence } \\
\text { (5-10 years). } \\
\text { Predictive for chemo and radiation } \\
\text { sensitive in high recurrence score } \\
\text { group. } \\
\text { Oncotype DX DCIS is predictive of } \\
\text { DCIS recurrence. } \\
\text { Benefits women who have had } \\
\text { surgery for DCIS, whether } \\
\text { additional adjuvant treatment } \\
\text { (radiotherapy or tamoxifen) is } \\
\text { needed based on their risk score. }\end{array}$ & $\begin{array}{l}\text { Continuous Recurrence Score (formerly triple risk } \\
\text { stratification; intermediate score discarded on basis } \\
\text { of TAILORx trial results): Low risk (RS 0-25; no } \\
\text { additional benefit with chemotherapy), High Risk } \\
\text { (RS 26-100; substantial chemotherapy benefit). } \\
\text { Risk score for ipsilateral recurrence (invasive or } \\
\text { DCIS); Low risk < 39, Intermediate risk 39-54, } \\
\text { High risk } \geq 55 \text {. }\end{array}$ & $\begin{array}{l}\text { TRANS ATAC, } \\
\text { NASBP B BA/B } 20, \\
\text { RxPONDER, } \\
\text { TAILORx, } \\
\text { ECOG-ACRIN, } \\
\text { Ontario study }\end{array}$ & $\begin{array}{l}\text { Considered the gold } \\
\text { standard in MGTs with } \\
\text { high amplification } \\
\text { efficiency, precision and } \\
\text { linearity. }\end{array}$ \\
\hline $\begin{array}{c}\text { MammaPrint } \\
\text { Agendia } \\
\text { [42-52] }\end{array}$ & $\begin{array}{l}\text { Fresh/frozen } \\
\text { or FFPE, } \\
\text { Microarray, } \\
\text { Centralized }\end{array}$ & $\begin{array}{l}\text { FDA, } \\
\text { St Gallen }\end{array}$ & $\begin{array}{l}\text { Stage I-II, } \\
0-3 \text { node+, } \\
\text { ER+ }\end{array}$ & $\begin{array}{l}\text { Prognostic for short-term distant } \\
\text { recurrence (0-5 years). } \\
\text { Predictive for chemoresponse in } \\
\text { high risk group, ER+ cancer. } \\
\text { Strong predictor of } 10 \text {-year } \\
\text { metastasis-free survival. }\end{array}$ & $\begin{array}{l}\text { Binary risk classification (MP low risk or MP high } \\
\text { risk) for recurrence without adjuvant chemotherapy. } \\
\text { Combined with BluePrint (a molecular subtyping } \\
\text { test) stratifies patients into four subgroups: } \\
\text { Luminal-type/MP Low Risk; Luminal-type/MP } \\
\text { High Risk; HER2-type and Basal-type. }\end{array}$ & $\begin{array}{l}\text { TRANSBIG, } \\
\text { MINDACT }\end{array}$ & $\begin{array}{l}\text { In contrast to Oncotype } \\
\text { DX, test was devised } \\
\text { from patients with no } \\
\text { hormonal (tamoxifen) } \\
\text { or chemo-therapy and } \\
\text { thus its robust } \\
\text { prognostic ability. } \\
\text { The test is endorsed for } \\
\text { the clinical high risk } \\
\text { group (OncotypeDx is } \\
\text { endorsed for clinical } \\
\text { low risk group). }\end{array}$ \\
\hline $\begin{array}{l}\text { Prosigna (PAM 50) } \\
\text { NanoString } \\
\text { Technologies } \\
\text { [53-61] }\end{array}$ & $\begin{array}{l}\text { FFPE, nCounter, } \\
\text { Decentralized; kit } \\
\text { compatible with other } \\
\text { pathology labs }\end{array}$ & $\begin{array}{l}\text { FDA, } \\
\text { NCCN, } \\
\text { ASCO, } \\
\text { St Gallen }\end{array}$ & $\begin{array}{l}\text { Stage I-III, } \\
\text { HR+ }\end{array}$ & $\begin{array}{l}\text { Prognostic for } 10 \text { year recurrence in } \\
\text { stage I-III. } \\
\text { Prognostic and predictive for } \\
\text { adjuvant tamoxifen. }\end{array}$ & $\begin{array}{l}\text { Continuous Rate of Recurrence (ROR) score: Low } \\
\text { risk (0-40), Intermediate risk (41-60), High risk } \\
(>61) .\end{array}$ & $\begin{array}{l}\text { Trans ATAC, } \\
\text { ABCSG8, } \\
\text { RxPONDER }\end{array}$ & $\begin{array}{l}\text { Its Prediction Analysis } \\
\text { of Microarrays (PAM) is } \\
\text { an almost fully } \\
\text { automated plattorm } \\
\text { technology. } \\
\text { RNA is extracted and } \\
\text { hybridized (by hand) } \\
\text { from FFPE tissue in } \\
\text { much smaller quantity } \\
\text { than other MGTs. }\end{array}$ \\
\hline $\begin{array}{l}\text { EndoPredict } \\
\text { Myriad Genetics } \\
{[62-65]}\end{array}$ & $\begin{array}{c}\text { FFPE, } \\
\text { RT-PCR, } \\
\text { Decentralized }\end{array}$ & $\begin{array}{c}\text { ASCO, } \\
\text { St Gallen,NCCN }\end{array}$ & $\begin{array}{l}\text { Early stage, } \\
\text { ER+,Her2- }\end{array}$ & $\begin{array}{l}\text { Prognostic for early ( } 0-5 \text { years) and } \\
\text { late (5-15 years) distant recurrence. } \\
\text { Predictive for benefit from both } \\
\text { adjuvant chemotherapy as well as } \\
\text { which patients can safely forgo } \\
\text { extended endocrine therapy } \\
\text { beyond five years. }\end{array}$ & $\begin{array}{l}\text { The multi-gene EP test (Figure } 2 \text { ) and clinical factors } \\
\text { (nodal status and tumor size) are combined into an } \\
\text { EPClin score stratifying patients into low- or } \\
\text { high-risk groups: EP low-risk (<5), EP high-risk } \\
(\geq 5) \text {; EPclin low-risk }(<3.3) \text {, EPclin high-risk }(\geq 3.3) \text {. }\end{array}$ & $\begin{array}{l}\text { GEICAM 9906, } \\
\text { ABCSG6 and } \\
\text { ABCSG8 }\end{array}$ & $\begin{array}{l}\text { EndoPredict is a } \\
\text { second-generation, } \\
\text { multigene } \\
\text { prognostic test. }\end{array}$ \\
\hline $\begin{array}{l}\text { Breast Cancer Index } \\
\text { Biotheranostics } \\
\text { [66-70] }\end{array}$ & $\begin{array}{l}\text { FPET, } \\
\text { Real time RT-PCR, } \\
\text { Centralized }\end{array}$ & $\begin{array}{c}\text { ASCO, } \\
\text { St Gallen }\end{array}$ & $\begin{array}{l}\text { Stage I-III, } \\
\text { HR+, } \\
\text { Her2-, } \\
\text { Node- }\end{array}$ & $\begin{array}{l}\text { Predictive for adjuvant } \\
\text { aromatase inhibitor. } \\
\text { Predictive for hormonal therapy for } \\
5 \text { additional years for total of } \\
10 \text { years. } \\
\text { Prognostic for late distant } \\
\text { recurrence (post-five years). }\end{array}$ & $\begin{array}{l}0-10 \text { year recurrence risk score is continuous: Low } \\
\text { risk } \mathrm{BCI}<5.0825 \text {, Intermediate risk } \mathrm{BCI} \geq 5.0825 \text { to } \\
6.5025 \text { and High risk } \mathrm{BCI}>6.5025 \text {. } \\
\text { Bimodal score informs late distant recurrence: Low } \\
\text { risk } \mathrm{BCI}<5.0825 \text {, and High risk } \mathrm{BCI} \geq 5.0825 \text {. } \\
\mathrm{BCI} \text { index for predictive utility (to direct adjuvant } \\
\text { aromatase inhibitor treatment) is determined with } \\
\text { the } \mathrm{H} / \mathrm{I} \text { ratio (Figure } 2 \text { ) and is just a High and } \\
\text { Low qualification. }\end{array}$ & $\begin{array}{l}\text { Trans } \\
\text { ATAC,Stockholm } \\
\text { trial }\end{array}$ & $\begin{array}{l}\text { Outperformed both } \\
\text { OncotypeDx and } \\
\text { Mammostrat in its } \\
5-10 \text { years' } \\
\text { prognostic ability. }\end{array}$ \\
\hline
\end{tabular}


The performance of six multigene signatures were compared in women with early ER-positive BC who underwent endocrine therapy for 5 years. These multigene signatures included the oncotype Dx recurrence score, the PAM50-based Prosigna risk of recurrence (ROR), the breast cancer index (BCI), EndoPredict (EPclin), the clinical treatment score, and the 4-marker immunohistochemical score. The BCI, EPclin, and the PAM50-based Prosigna ROR showed significant prognostic value for predicting the overall and late distant recurrence in patients with lymph node (LN)-negative disease. The results from this telling study have proven useful for guiding oncologists and patients in choosing the most suitable testing to inform decisions regarding chemotherapy and/or extended endocrine therapy. These tests, however, have provided limited prognostic information for patients with node-positive disease [72].

Identifying specific mutations such as in the BRCA1, BRCA2, PALB2 and PTEN genes by sequencing, can be especially useful in selecting $B C$ patients who may be eligible for poly ADP-ribose polymerase (PARP) inhibitors [73]. Comprehensive BRCA testing is offered by multiple companies to identify BC patients with germline BRCA mutations. The myCHoice HRD (Myriad Genetics) CDx is a next-generation sequencing homologous recombination deficiency (HRD) assay that assesses both $B R C A 1$ and $B R C A 2$ as well as tumoral genomic instability. The assay uses DNA extracted from FFPE or frozen tumor tissue and labels a tumor as homologous recombination-deficient or -nondeficient, thus identifying patients who are most likely to benefit from treatment with PARP inhibitors. The BRACAnalysis CDx (Myriad Genetics) is an FDA-approved test for BRCA1 and BRCA2 for selecting patients suitable for olaparib treatment $[74,75]$.

\subsection{Number of Risk Categories: An Ongoing Debate}

Of all aforementioned BC assays, only two prognostic assays, namely, Oncotype DX and Prosigna, originally assigned triple-category risk groups. However, Oncotype DX has recently discarded the intermediate recurrence score group. The intermediate recurrence score (RS) (initially $18 \leq \mathrm{RS} \leq 30$; re-classified as 11-25) in Oncotype DX had arguably been a grey area, leaving many women uncertain and concerned about their best treatment options (to omit chemotherapy or not) $[29,33]$. To address this issue, in 2006, began the TAILORx Study, one of the largest, randomized adjuvant BC treatment trials (in early stage, hormone-receptor-positive, HER2 negative, axillary node-negative BC patients). The intermediate group (RS 11-25) were randomly assigned to receive hormone therapy alone or hormone therapy plus adjuvant chemotherapy [27]. The results published in 2018 showed that women in this group did not additionally benefit from chemotherapy [76]. In the wake of these results, the intermediate RS group was eliminated and Oncotype DX now provides a binary stratification, that is, a low (0-25) or high (26-100) score with the former deriving no benefit from chemotherapy and the latter benefitting substantially from it. Thus, there is only one true triple-category risk group assay which is commercially available for breast cancer prognostication. The intermediate score category of the FDA-endorsed Prosigna PAM50-based MGT follows the ROR scoring system based on the LN spread of $\mathrm{BC}$. If the $\mathrm{LN}$ is not affected (node-negative), the intermediate range is $41 \leq \mathrm{ROR} \leq 60$. However, if one or more (typically 1-3) LNs are affected, only a bimodal score is assigned. Several studies have shown that the node-negative ROR score is a better risk discriminator than the Oncotype DX RS [58].

\subsection{Gene-Based Prognostic Assays: The Major Takeaways}

In summary, MGTs offer several advantages. MGTs assign appropriate weightage to each variable and optimally extract information provided by multiple continuous variables. The information they provide is robust due to redundancy by capturing similar information from multiple genes. Even though these tests require specialized expertise to perform and interpret the results, overall, they prove to be cost-effective. Gene expression signatures are, however, unable to capture the prognostic information contributed by variables, such as tumor size or LN spread status, that lack an equivalent gene expression imprint. Therefore, there is a need to elevate the use of these clinicopathologic prognostic variables from merely providing complementary information to their incorporation as integral components of multivariate clinicogenomic risk models. These models could be built for 
distinct subtypes of $\mathrm{BC}$ because the prognostic value of each variable varies with the subtype and its unique tumor biology. In this regard, recently, Sparano et al., determined whether clinical risk assessment i.e., integrating tumor size and histologic grade, added prognostic and/or predictive information to the Oncotype DX RS. This was accomplished via secondary analyses of the TAILORx trial, and the results concluded that combining these information (from binary clinical-risk stratification and RS), provided prognostic information but was not predictive of chemotherapy benefit [77].

As the currently available MGTs assess the different pathways/gene sets, there remains the issue of discordance in risk assignment for a given patient sample by different MGTs. This ambiguity poses a challenge and increases the practical difficulty for clinicians in recommending a particular test, necessitating a head-on-head comparison of the MGTs. Although the prognostic gene signatures are being applied in clinical research trials, their ability to predict response to specific therapeutic agents is not as clear-cut. They are yet to graduate into routine clinical use for BC management. Furthermore, the gene expression-based tests focus only on the transcriptome, and it is becoming increasingly clear that gene expression and proteomic landscapes can diverge substantially. The MGTs entail gene expression profiling of a single sample from a tumor and evaluating a limited number of genes. They are thus, unable to adequately capture several aspects of the tumor's phenotype, including intratumoral heterogeneity, the tumor microenvironment, and profiles of tumor infiltrating cells, all of which profoundly influence tumor biology and patient prognosis. Moreover, the current gene panels do not inform about driver mutations and epigenetic events involved in disease progression. Intratumoral heterogeneity has implications in therapy resistance as well as cancer progression and recurrence. Early detection of resistant subclones and tracking evolution of tumors requires longitudinal tissue sampling which is not practically feasible. This information can be gleaned by liquid biopsies instead, that offer a relatively non-invasive real-time monitoring method for serial sampling of circulating tumor DNA and tumor cells.

In many ways, nucleic acid markers seem ideal for elucidating disease pathology, and a fair number of molecular diagnostic tests exploit genetic variations (such as single-nucleotide polymorphisms [SNPs], mutations, and copy number variations [CNVs] that exist between abnormal and unaffected genomes. However, protein-based biomarkers more accurately profile the more relevant workhorses of the cell (functional proteins), and allow the capture of information pertaining to their subcellular localization, thus providing an edge over their nucleic acid counterparts. Furthermore, protein-based biomarkers are able to capture intratumoral heterogeneity and the expression of biomarkers in the tumor microenvironment, combining biological with morphological information. The following sections focus on the development of assays to analyse secreted protein molecules, circulating tumor cells and nucleic acids.

\section{Liquid Biopsy Holds Promise for Guiding Breast Cancer Management}

Liquid biopsy involves the analysis of circulating tumor cells (CTCs), cell-free circulating nucleic acids (circulating tumor DNA [ctDNA], and microRNA [miRNA]) and exosomes, released into the peripheral blood or urine from the primary tumor and/or metastatic deposits. It has recently emerged as a noninvasive prognostic, surveillance, and predictive tool in both early and metastatic BC that may complement, augment, or replace (in some cases) the use of tissue biopsy. The ease of sampling combined with the ability to monitor tumor burden or mutation changes temporally with ctDNA, allows for disease monitoring, the evaluation of therapeutic response, and molecular profiling in the advanced disease setting to determine therapeutic targets. The research in using ctDNA to tailor treatments has shown encouraging results. For example, the BELLE-2 trial and the SoFEA trial have demonstrated the clinical applicability of ctDNA to detect PI3K and ESR1 mutations, respectively, and the benefit of targeting these mutations with PI3K inhibitors and fulvestrant, respectively $[78,79]$. The NeoALTTO phase III trial found that the detection of ctDNA before starting NAC (neoadjuvant chemotherapy) correlated with lower pCR rates [80]. Thus, measuring ctDNA may aid in predicting the response to NAC. Another study in a series of patients with advanced breast cancer, showed that mutation 
levels in plasma samples (liquid biopsies) can provide similar information about clonal hierarchy as that determined by sequencing tissue biopsies. Thus, ctDNA can help characterize multifocal clonal evolution in metastatic cancers [81]. Furthermore, Chen et al., have used next generation sequencing (NGS) to analyze ctDNA and found a high specificity for predicting disease recurrence but a low sensitivity, possibly due to the low number of mutated DNA molecules in circulation [82].

In addition to ctDNA, CTCs may be used to predict the risk of relapse in early-stage disease [83]. The ECOG-ACRIN E5103 trial, in which samples were collected between 4.5 and 7.5 years after diagnosis, reported that patients who were positive for CTCs had a 21.7-fold higher chance of recurrence compared to those who were CTC-negative [83]. While CTC testing at a single time point is effective for risk stratification of patients, more studies are needed to define how these tests can be used in the clinical setting to make meaningful clinical decisions. As the circulation rate of CTCs is one per $1 \times 10^{9}$ normal blood cells in metastatic cancer, their identification and isolation is particularly difficult [84]. Despite this, recent technologic advances have spawned new approaches for the selection and capture of CTCs, such as CTC-based assays that exhibit high specificity and low signal-to-noise ratio, especially in the detection of early-stage BC.

The CELLSEARCH Circulating Tumor Cell Kit (Menarini-Silicon Biosystems), a real time liquid biopsy currently licensed by Janssen Diagnostics among other companies, is the only CTC technology accredited by the FDA for the management of patients with metastatic BC. The semi-automated system uses a simple, actionable blood test based on an immunomagnetic enrichment technology [85]. A cut-off value of $\geq 5$ CTCs per $7.5 \mathrm{~mL}$ of blood has been established, separating patients into shorter or longer survival groups [86-88]. Using the CELLSEARCH system, a few studies have validated CTC count as an independent prognostic factor for both metastatic and nonmetastatic $\mathrm{BC}$, and found it to be more reproducible than radiology, detecting disease progression ahead by several weeks [88-90]. Monitoring CTC count during therapy potentially allows for the early detection of resistance to therapy. Due to its clinical validation and FDA approval, the assay has gained prominence as a type of gold standard within the field. However, the system uses expensive equipment and its cost is a major limitation. Furthermore, CTC capture is based on the presence of antigens on the cell surface that may result in both false-positive and false-negative results, with false-positives increasing during inflammatory conditions [91].

The EPISPOT assay (EPithelial Immuno SPOT) is also used to detect living CTCs although it employs a strategy different from CELLSEARCH [92,93]. A multicenter study observed an improved stratification of patients with metastatic BC (low- and high-risk groups) upon adding CTC status as measured by CELLSEARCH to that by EPISPOT, and found that a combination of both assays was the strongest predictor of OS (overall survival) [94].

The Nagrath Laboratory at the University of Michigan has created a superior CTC isolation technology in the form of a prototype wearable that continuously and directly traps CTCs from the patient's blood. As the remaining blood products are returned post-CTC enrichment, larger blood volumes can be scanned, providing a lucid picture of tumor cell heterogeneity. This counters one of the major shortcomings in the current CTC technologies that rely on smaller blood draws, thus suffering from statistical variability [95].

When integrated at different points in the disease course, liquid biopsies can proffer information over and above that provided by standard clinicopathologic variables alone. Compared with CTC-based assays, ctDNA assays are superior when it comes to providing an individualized snapshot of a patient's disease status, and they have greater sensitivity for early cancer detection. Unlike CTCs, ctDNA capture does not require specialized equipment [96]. Although ctDNA and CTC assays harbor immense potential, a lack of stringent studies and robust comparative assays are impairing their clinical application. 


\subsection{Serum Protein Markers}

Videssa Breast (Provista Diagnostics) is a combinatorial multi-protein biomarker blood test for BC that evaluates 11 serum protein biomarkers (SPBs) and 33 tumor-associated autoantibodies (TAAbs) (Figure 2). The data are then combined with the patient age into a logistic regression algorithm, and the outcome is defined as a high protein signature (HPS) or low protein signature (LPS) [97]. One study validated the use of this noninvasive, actionable tool in detecting BC in women aged 50 years or younger with a low or intermediate risk who had abnormal or difficult-to-interpret imaging results (BI-RADS scores of 3 and 4). The Videssa Breast test used in conjunction with imaging results improved the diagnostic accuracy and reduced unnecessary biopsy by up to $67 \%$ when applied to cases that presented a challenging clinical assessment (compared with imaging alone), and the negative predictive value was $99 \%$. Thus, in cases where mammogram results are abnormal, this tool can help clinicians identify the patients who are highly unlikely to have BC [98]. Another study demonstrated that the assay could reliably rule out BC in women with both dense and non-dense breasts [97].

A few FDA approved serum BC markers worth mentioning are the Carcinoma Antigen 15-3 (CA 15-3), Carcinoma Antigen 27-29 (CA 27-29) and PIK3CA. These have proved useful in monitoring the disease course in metastatic BC [99]. The clinical guidelines from the ASCO recommends using CA $15-3$ and CA $27-29$ as adjunctive assessments in informing treatment decisions ( $a 25 \%$ increase is suggested clinically significant) [100].

\subsection{Circulating microRNAs}

Several microRNAs (miRNAs) are dysregulated in BC [101]. This knowledge, coupled with the ease of isolation and their relative stability through sample processing and isolation, makes circulating miRNAs an attractive biomarker. Despite extensive research, clinically useful miRNA signatures elude oncology practice. Owing to the differences in patient selection, miRNA isolation and measurement techniques, low levels of miRNAs, concurrent diseases, effects of therapy, and insufficient studies validating its clinical utility, there has been little consensus among different miRNA panels identified so far. The future course lies in determining the most appropriate fluid for measuring miRNA (whole blood, serum or plasma), identifying the tissue of origin, standardizing the sample collection, handling and the methods of measurement, as well as the normalization of miRNA concentrations [102,103].

\section{Metabolomics in Breast Cancer Prognosis}

Equipped with the information that cancer cells display altered metabolism, a signature indicative of the presence and behavior of cancer can be generated via metabolite profiling. The information regarding the variant levels of metabolites between healthy subjects and those with cancer can be obtained by combining techniques of nuclear magnetic resonance (NMR) spectroscopy and mass spectrometry with multivariate statistical analysis. The application of metabolomics in cancer diagnostics and therapeutics is fairly new and promising, as it can provide a much-needed link between the genotype and phenotype together with some insight into oncogenesis [104]. Moreover, various studies have determined the use of this approach in predicting BC prognostic factors (ER and PR status) in tissue samples, differentiating early-stage from metastatic disease patients using serum samples, predicting BC recurrence, and predicting the response to NAC [105-110]. Additionally, metabolomics may detect micrometastasis in patients with early BC [111]. Metabolomics can also be used to search for drug metabolites in serum, in order to monitor the metabolic response to adjuvant therapy [112]. The study of the cancer metabolome is being used to identify biomarkers and potential therapeutic targets, thus also paving the way for pharmacometabolomics in cancer [104]. Akin to proteomics and transcriptomics, the assays for metabolite profiling, once established, are relatively inexpensive, rapid, and automatable [113]. Metabolomics has unbroached potential, and in the near future this new, rapidly expanding field promises to be a prime contributor to cancer diagnostics and therapeutics. 


\section{Tumor Microenvironment-Based Biomarkers: Tumor Infiltrating Lymphocytes as Prognostic and Predictive Variables in Breast Cancer}

Tumor infiltrating lymphocytes (TILs) are an integral part of the tumor microenvironment and have been observed in all BC subtypes, with high counts detected in high-grade, aggressive tumors [114]. Particularly in triple-negative BC (TNBC) and HER2-positive BC, TILs display prognostic and predictive value [115-117]. In general, higher TIL density is associated with good prognosis and can be correlated with pathologic complete response (pCR) [115,118-127]. However, a standard method for evaluating TILs for effective integration into clinical histopathologic practice remains lacking. In 2014, an international TILs working group published a series of methodologic recommendations for evaluating TILs in BC using hematoxylin and eosin ( $\mathrm{H}$ and $\mathrm{E}$ )-stained tumor sections, and recommended that TILs be reported for the stromal compartment and assessed as a continuous parameter [128]. Later, Hida et al. modified this scoring system and classified the triple-negative and HER2-positive BCs into low $(<10 \%)$, intermediate and high $(>50 \%)$ TIL scores [129].

Even though several studies have demonstrated the prognostic value of TIL assessment, and standardized methods are now available, the St. Gallen International Breast Cancer Conference guidelines from 2017 still do not require the inclusion of TILs in routine pathology reporting [130]. The highlights from the 2019 conference, however, do mention the potential of TILs for further improving risk stratification [131]. The clinical utility of TILs may lie not in isolation but in conjunction with other clinicopathologic variables, such as the patient age, disease stage, alterations in the genome, and other microenvironment factors [132], and their utility is likely gain prominence as immunotherapies are introduced into clinical settings. In addition, the incorporation of TIL assessment as a prognostic variable in multivariate statistical analysis is likely to further increase the role of TILs in the near future.

\section{Neoantigens as Biomarkers of Treatment Response}

Among emerging biomarkers, neoantigens display great promise in predicting responses to immunotherapy [133]. Exome sequencing along with protein mass spectrometry has led to the identification of patient-specific tumor neoantigens that result from somatic mutations in the tumor tissue. As neoantigens correlate well with the overall somatic mutation rate, as well as with the clinical response, the assays based on them can be used to measure the drug response. For example, a neoantigen landscape has been described in tumors with a strong response to CTLA-4 blockade [134].

\section{Digital Pathology and Tissue Phenome Analysis}

Pathology has always been a driver behind precision medicine, and a $\mathrm{H}$ and E-stained slide is the touchstone of a pathologic analysis, especially when the tissue amounts are insufficient for molecular analysis [135]. Histopathology requires large volumes of biologic tissues to be scrutinized by highly skilled pathologists, making it time-consuming, labor-intensive, and error-prone. The advances in image analysis of stained slides now enable the objective, reproducible, and automated quantification of features, including multiple co-registered features, subcellular expression patterns of biomarkers, and cellular morphometrics from digitized tissue sections. Many of these features can be captured as continuous data, and the distances between the features can also be calculated so that spatial statistics and other exhaustive computing analyses can be employed to reveal new and potentially actionable insights that could not be uncovered by the human eye alone [136-140].

A 2017 study by Bejnordi et al. showed the use of convolutional neural networks (CNN) in diagnosing and classifying whole-slide images from breast biopsies into three classes (normal/benign, DCIS, and invasive ductal carcinoma [IDC]). The overall classification accuracy for their system was 81.3\% [141]. More recently, Sergey et al. have devised a novel machine learning based whole slide image analysis tool that can significantly predict recurrence in DCIS patients and identify those that may benefit from additional therapy [142]. In addition, Google is applying deep-content learning technology to build an automated detection algorithm that will complement the pathologist workflow. In scanning LN metastasis, their approach demonstrated substantially lower false-negative rates 
compared with those ascertained by pathologists [143]. Furthermore, the deep neural networks (DNNs) function by anatomizing images into pixels and sequentially combining them into features representing specific diagnostic patterns. They can also be trained to integrate follow-up studies into diagnostic algorithms, thus expanding their intelligence and enhancing the overall performance. Foreseeable is a cloud-based online DNN image analysis tool that can provide consensus on cancer diagnosis, which can be meaningful for pathologists working at small centers in receiving timely, cost-effective second opinions [144]. Although deep-learning based technologies are currently at an incipient stage, they are poised to become indispensable to personalized and precision oncology in the near future.

\section{Scoring Centrosome Amplification: An Emerging Prognostic Marker}

Centrosome amplification (CA) (i.e., an abnormal increase in the number and/or volume of centrosomes) is commonly observed in pre-invasive lesions, such as DCIS as well as invasive breast tumors. Its reputation as a BC prognostic marker strengthened in light of research that showed, high-risk BC subtypes such as TNBC patients, display higher CA (and overexpression of CA associated genes), which is associated with tumor aggressiveness and poor clinical outcomes [145]. Furthermore, CA status is connected to metastatic risk and progression free survival. A different study revealed that CA strongly correlates with higher BC grade and stage, and leads to chromosomal instability, thus driving intratumoral heterogeneity [146]. This formed the basis for a continued focus on, and development of CA as a scorable marker. Profiling CA conventionally, is technically challenging and requires advanced approaches to enhance its clinical utility.

\subsection{Immunofluorescence-Based Three-Dimensional Image Analysis Yields a CA Score for Ductal Carcinoma In Situ Stratification}

Mittal et al. have rigorously quantitated structural amplification of centrosomes in tumor samples by integrating immunofluorescence confocal microscopy with digital image analysis via an IP-protected semi-automated pipeline technology. This yields a quantifiable biomarker, the centrosome amplification score (CAS), which can stratify DCIS into low- and high-CA categories, the latter associated with a greater risk of local recurrence. The CAS may prove to be superior to the VNPI in terms of predicting the risk of local recurrence for women with DCIS of the breast [147].

\subsection{CA20: A Transcriptomic Signature}

Ogden et al. identified and validated CA20, a 20 gene CA transcriptomic signature (consisting of centrosome structural genes and genes involved in inducing CA), in breast tumors. CA20 is an independent predictor of poor survival and a high score is indicative of high chromosomal instability (CIN) and tumor aggressiveness [148]. Later, Almeida et al. in their pan-cancer computational analysis (from The Cancer Genome Atlas [TCGA] cohort) confirmed the association of CA20 with clinical and molecular features of BC as well as with CIN. In their study, CA20 correlated with poor prognosis in eight different cancers (including BC) and can aid stratification of patients with BC. In concert with immunofluorescence, CA20 can prove to be a valuable marker [149].

\section{Prognostic Breast Cancer Staging}

A major challenge for large-scale precision medicine research is in harmonizing data from different sources. This can be overcome by standardizing nomenclature and developing sophisticated metadata descriptions that enable data integration, and by enabling the portable reproducible reanalysis of datasets. In this context, two prominent BC staging systems are being discussed, the American Joint Committee on Cancer (AJCC) Tumor/Node/Metastasis (TNM) classification and the Neo-Bioscore system (University of Texas MD Anderson Cancer Center).

Recognizing the need to incorporate biologic factors (tumor grade, proliferation rate, and ER/PR/HER2 expression) and gene expression-based prognostic panels, in addition to the traditional anatomic factors into its staging system, the AJCC recently extensively revised its eighth edition of 
the TNM classification system, which remains the worldwide basis for BC staging. Furthermore, the AJCC Breast Expert Panel has recommended providing two BC Prognostic Stage tables; the Clinical Prognostic Stage Group (based on history, physical examination, imaging studies, and relevant biopsy results) and the Pathologic Prognostic Stage Group (for patients who have surgical resection as the initial treatment).

Furthermore, emphasizing and lending credence to the importance of tumor biology as critical for $\mathrm{BC}$ prognosis, researchers at the MD Anderson Cancer Center have developed the Neo-Bioscore system, a new BC staging system that builds on their previously developed CPS+EG staging system. The CPS+EG system predated the routine use of trastuzumab (Herceptin) in the neoadjuvant setting, and uses the clinical stage of cancer before NAC treatment and the pathologic stage post-NAC (CPS score), the estrogen receptor status (E), and cancer grade $(G)$. The system generates a score that helps estimate 5 -year distant metastasis-free survival post-NAC, but is unable to provide prognostic information for patients with HER2-positive disease. The Neo-Bioscore staging system overcomes this limitation by incorporating HER2 status into the score [150].

\section{Future Perspectives}

Although NGS, the backbone of multigene assays and whole-exome/genome sequencing, has vastly improved our understanding of the origin and evolution of cancer, it has generated a deluge of information and new quandaries. The clinical interpretation of the results (e.g., how to differentiate among the errors, polymorphisms, and causal mutations), as well as properly assigning pathogenicity to variants, is a work in progress. Importantly, the possibility of overinterpreting NGS testing results may lead to unnecessary medical action and add to the high levels of anxiety experienced by patients with BC and their families. Cancer gene panels do provide a middle ground by addressing the clinical questions while avoiding information overload. Additionally, NGS data yield variants of uncertain significance and incidental findings (i.e., findings unrelated to the condition under investigation) that raise ethical-legal concerns. Moreover, privacy issues are inherent when placing genomic data in the public domain and sharing genetic information, particularly regarding heritable mutations, with genetic relatives. Clearly, physician training has become crucial. Physicians need to understand the value/limitations of the data derived from these assays in the context of clinical care, and collaborate closely with genetic counselors to help their patients receive the best treatments possible.

The global profiling of an individual's tumor at the genomic, proteomic, transcriptomic, metabolomic, and other - omic levels is technologically achievable now. A case in point is GPS Cancer, a molecular test by NantHealth that integrates whole-genome and whole-transcriptome sequencing with quantitative targeted proteomics of both normal and cancerous tissue. The presence of protein biomarkers in tumor cells at levels as low as attomoles/ $\mu \mathrm{g}$ of tumor tissue can be ascertained, providing actionable insights for immunotherapy, chemotherapy, targeted therapy, hormonal therapy, and monoclonal antibody therapy. DNA, RNA, proteomic, copy number variant, and other information can now be seamlessly woven together using sophisticated big data analytics to generate probabilistic causal networks, improving the chances of identifying the perturbations that drive a tumor's biology, or enabling a deeper segmentation of heterogeneous patient cohorts for precision medicine. However, all data are not created equal, and multi-omic analysis can be time- and cost-prohibitive. Thus, different variables might need to be accorded different weights depending on the subtype of $\mathrm{BC}$ and/or the stage of disease (early versus advanced) to optimize the treatment and achieve the best outcomes possible. There is also a pressing need for multivariate prognostic/predictive models that are not plagued by a lack of biomarker standardization and inter-observer variability. A useful addition to the current models would be that of a monitoring tool/biomarker (for a period $>10$ years) to address the issue of late disease recurrence.

Projects like the International Cancer Genome Consortium (ICGC) and The Cancer Genome Atlas (TCGA) are working toward a shared goal of cataloging oncogenic mutations in order to further our understanding of the genetic basis of cancer, which can have a direct bearing on the diagnosis 
and management of the disease. The TCGA has generated exhaustive, multidimensional maps of crucial genomic alterations in 33 cancer types. The ICGC is coordinating genomics studies in tumors from 50 different cancer types and/or subtypes. The International Cancer Genome Consortium for Medicine (ICGCmed) will link the (as yet) aggregated genomics data to clinical and health information and response to therapies. The concerted efforts of these and other similar global projects are generating huge amounts of data (e.g., the TCGA dataset, accessible to the public, is currently pegged at 2.5 petabytes) that comprise RNA sequencing, proteomic, and imaging data, apart from genomic data.

To effectively employ NGS and the various biomarkers in the field of precision medicine requires complement with next-generation functional diagnostic technologies. The next-generation functional testing approach works around the limitations of traditional chemosensitivity tests by involving new cultivation methods for patient-derived tumor cells ex vivo, entailing the monitoring of live tumor states, and exposing a patient's tumor biopsy ex vivo to drugs, thus directly revealing the cellular response to the applied agent. This does not require prior knowledge of a drug's mechanism of action, and if the tumor cells are sensitive (usually measured by the level of tumor cell death), the drug can be clinically administered promptly [151]. Novel methods of tumor manipulation have been established that include organoids developed from cultivating single patient-derived cells, or artificial organotypic cultures developed from multiple patient-derived cells. Organoids grow in three dimensions, proving to be superior to two-dimensional cultures by more accurately mirroring the endogenous architecture of the parent tissue [152-154]. In addition, patient-derived xenograft (PDX) mouse models (in which biopsy material is subcutaneously or orthotopically implanted and expanded in vivo) can be generated that more faithfully recapitulate the patient's tumor environment [155] and can be used as avatars for drug testing. Another cutting-edge development involves in situ functional diagnostics, wherein the drug effects can be directly tested with micro-dosing of solid tumors using novel devices inside the patient $[156,157]$. These tests require further preclinical and clinical validation to be of value for treating patients with $\mathrm{BC}$, and to be incorporated into the clinical setting.

\section{Conclusions}

Cutting- edge - omics technologies, digital pathology, and new multibiomarker assays, together with clinical annotation, have granted unprecedented insights into the biology driving tumor development and the exploitable vulnerabilities, and are daily transforming the management of $\mathrm{BC}$. The key lies in the effective integration of these multi-platform data and mining it for meaningful information. While the field of precision medicine in BC is making remarkable strides, it is important not to lose sight of the potential roadblocks ahead and the limitations of the current biomarkers and technologies. One such limitation is the lack of sensitive and specific biomarkers for early detection of BC. Another matter of concern is the copious amounts of genomic data being generated currently, which is only set to multiply in the future. Based on the current infrastructure, most research organizations will struggle to store and manage these data, let alone optimally analyze them. There is also the problem of underrepresentation of minority populations in most research cohorts. Detecting significantly mutated genes and all alterations involved, requires the interrogation of thousands of samples. There is thus a pressing need for increasing sample sizes for precision medicine research. Finally, increasing cohort size tackles the problem that not all genetic variants associated with disease are equally common, or equally easy to detect. As the number of sequenced genomes grows, it may be found that rare variants make important contributions to many diseases.

Funding: This research was funded by National Institutes of Health (NIH)/National Cancer Institute (NCI) BY grant number UO1 CA179671.

Conflicts of Interest: The authors declare no conflicts of interest. 


\section{References}

1. Haybittle, J.L.; Blamey, R.W.; Elston, C.W.; Johnson, J.; Doyle, P.J.; Campbell, F.C.; Nicholson, R.I.; Griffiths, K. A prognostic index in primary breast cancer. Br. J. Cancer 1982, 45, 361-366. [CrossRef] [PubMed]

2. Green, A.R.; Soria, D.; Powe, D.G.; Nolan, C.C.; Aleskandarany, M.; Szasz, M.A.; Tokes, A.M.; Ball, G.R.; Garibaldi, J.M.; Rakha, E.A.; et al. Nottingham prognostic index plus (NPI+) predicts risk of distant metastases in primary breast cancer. Breast Cancer Res. Treat. 2016, 157, 65-75. [CrossRef] [PubMed]

3. Kwon, J.; Eom, K.Y.; Koo, T.R.; Kim, B.H.; Kang, E.; Kim, S.W.; Kim, Y.J.; Park, S.Y.; Kim, I.A. A Prognostic Model for Patients with Triple-Negative Breast Cancer: Importance of the Modified Nottingham Prognostic Index and Age. J. Breast Cancer 2017, 20, 65-73. [CrossRef] [PubMed]

4. Silverstein, J.M.; Lagios, M.D. Treatment selection for patients with ductal carcinoma in situ (DCIS) of the breast using the University of Southern California/Van Nuys (USC/VNPI) prognostic index. Breast J. 2015, 21, 127-132. [CrossRef] [PubMed]

5. Dowsett, M.; Sestak, I.; Regan, M.M.; Dodson, A.; Viale, G.; Thurlimann, B.; Colleoni, M.; Cuzick, J. Integration of Clinical Variables for the Prediction of Late Distant Recurrence in Patients With Estrogen Receptor-Positive Breast Cancer Treated with 5 Years of Endocrine Therapy: CTS5. J. Clin. Oncol. 2018, 36, 1941-1948. [CrossRef] [PubMed]

6. Wazir, U.; Mokbel, K.; Carmichael, A.; Mokbel, K. Are online prediction tools a valid alternative to genomic profiling in the context of systemic treatment of ER-positive breast cancer? Cell. Mol. Biol. Lett. 2017, $22,20$. [CrossRef]

7. Cuzick, J.; Dowsett, M.; Pineda, S.; Wale, C.; Salter, J.; Quinn, E.; Zabaglo, L.; Mallon, E.; Green, A.R.; Ellis, I.O.; et al. Prognostic value of a combined estrogen receptor, progesterone receptor, Ki-67, and human epidermal growth factor receptor 2 immunohistochemical score and comparison with the Genomic Health recurrence score in early breast cancer. J. Clin. Oncol. 2011, 29, 4273-4278. [CrossRef]

8. Vieira, A.F.; Schmitt, F. An Update on Breast Cancer Multigene Prognostic Tests-Emergent Clinical Biomarkers. Front. Med. 2018, 5, 248. [CrossRef]

9. Lakhanpal, R.; Sestak, I.; Shadbolt, B.; Bennett, G.M.; Brown, M.; Phillips, T.; Zhang, Y.; Bullman, A.; Rezo, A. IHC4 score plus clinical treatment score predicts locoregional recurrence in early breast cancer. Breast 2016, 29, 147-152. [CrossRef]

10. Look, M.P.; van Putten, W.L.; Duffy, M.J.; Harbeck, N.; Christensen, I.J.; Thomssen, C.; Kates, R.; Spyratos, F.; Ferno, M.; Eppenberger-Castori, S.; et al. Pooled analysis of prognostic impact of urokinase-type plasminogen activator and its inhibitor PAI-1 in 8377 breast cancer patients. J. Natl. Cancer Inst. 2002, 94, 116-128. [CrossRef]

11. Janicke, F.; Prechtl, A.; Thomssen, C.; Harbeck, N.; Meisner, C.; Untch, M.; Sweep, C.G.; Selbmann, H.K.; Graeff, H.; Schmitt, M.; et al. Randomized adjuvant chemotherapy trial in high-risk, lymph node-negative breast cancer patients identified by urokinase-type plasminogen activator and plasminogen activator inhibitor type 1. J. Natl. Cancer Inst. 2001, 93, 913-920. [CrossRef] [PubMed]

12. Harbeck, N.; Schmitt, M.; Meisner, C.; Friedel, C.; Untch, M.; Schmidt, M.; Sweep, C.G.; Lisboa, B.W.; Lux, M.P.; Beck, T.; et al. Ten-year analysis of the prospective multicentre Chemo-N0 trial validates American Society of Clinical Oncology (ASCO)-recommended biomarkers uPA and PAI-1 for therapy decision making in node-negative breast cancer patients. Eur. J. Cancer 2013, 49, 1825-1835. [CrossRef] [PubMed]

13. Foekens, J.A.; Peters, H.A.; Look, M.P.; Portengen, H.; Schmitt, M.; Kramer, M.D.; Brunner, N.; Janicke, F.; Gelder, M.E.; Henzen-Logmans, S.C.; et al. The urokinase system of plasminogen activation and prognosis in 2780 breast cancer patients. Cancer Res. 2000, 60, 636-643. [PubMed]

14. Harris, L.; Fritsche, H.; Mennel, R.; Norton, L.; Ravdin, P.; Taube, S.; Somerfield, M.R.; Hayes, D.F.; Bast, R.C., Jr.; American Society of Clinical Oncology. American Society of Clinical Oncology 2007 update of recommendations for the use of tumor markers in breast cancer. J. Clin. Oncol. 2007, 25, 5287-5312. [CrossRef] [PubMed]

15. Bellocq, J.P.; Luporsi, E.; Barriere, J.; Bonastre, J.; Chetritt, J.; le Corroller, A.G.; de Cremoux, P.; Fina, F.; Gauchez, A.S.; Kassab-Chahmi, D.; et al. uPA/PAI-1, Oncotype DX, MammaPrint((R)). Prognosis and predictive values for clinical utility in breast cancer management. Ann. Pathol. 2014, 34, 349-351. [CrossRef] [PubMed]

16. Nicolini, A.; Ferrari, P.; Duffy, M.J. Prognostic and predictive biomarkers in breast cancer: Past, present and future. Semin. Cancer Biol. 2018, 52, 56-73. [CrossRef] 
17. Volker, H.U.; Weigel, M.; Strehl, A.; Frey, L. Levels of uPA and PAI-1 in breast cancer and its correlation to Ki67-index and results of a 21-multigene-array. Diagn. Pathol. 2018, 13, 67. [CrossRef]

18. Dixon, A.R.; Bathany, C.; Tsuei, M.; White, J.; Barald, K.F.; Takayama, S. Recent developments in multiplexing techniques for immunohistochemistry. Expert. Rev. Mol. Diagn. 2015, 15, 1171-1186. [CrossRef]

19. Ross, J.S.; Hatzis, C.; Symmans, W.F.; Pusztai, L.; Hortobagyi, G.N. Commercialized multigene predictors of clinical outcome for breast cancer. Oncologist 2008, 13, 477-493. [CrossRef]

20. Paik, S.; Shak, S.; Tang, G.; Kim, C.; Baker, J.; Cronin, M.; Baehner, F.L.; Walker, M.G.; Watson, D.; Park, T.; et al. A multigene assay to predict recurrence of tamoxifen-treated, node-negative breast cancer. N. Engl. J. Med. 2004, 351, 2817-2826. [CrossRef]

21. Esteban, J.; Baker, J.; Cronin, M.; Liu, M.-L.; Llamas, M.; Walker, M.; Mena, R.; Shak, S. Tumor gene expression and prognosis in breast cancer: Multi-gene RT-PCR assay of paraffin-embedded tissue. Proc. Am. Soc. Clin. Oncol. 2003, 22, A3416.

22. Cobleigh, M.; Bitterman, P.; Baker, J.; Cronin, M.; Liu, M.-L.; Borchik, R.; Tabesh, B.; Mosquera, J.-M.; Walker, M.; Shak, S. Tumor gene expression predicts distant disease-free survival (DDFS) in breast cancer patients with 10 or more positive nodes: High throughput RT-PCR assay of paraffin-embedded tumor tissues. Proc. Am. Soc. Clin. Oncol. 2003, 22, A3415.

23. Habel, L.A.; Shak, S.; Jacobs, M.K.; Capra, A.; Alexander, C.; Pho, M.; Baker, J.; Walker, M.; Watson, D.; Hackett, J.; et al. A population-based study of tumor gene expression and risk of breast cancer death among lymph node-negative patients. Breast Cancer Res. 2006, 8, R25. [CrossRef] [PubMed]

24. Cronin, M.; Pho, M.; Dutta, D.; Stephans, J.C.; Shak, S.; Kiefer, M.C.; Esteban, J.M.; Baker, J.B. Measurement of gene expression in archival paraffin-embedded tissues: Development and performance of a 92-gene reverse transcriptase-polymerase chain reaction assay. Am. J. Pathol. 2004, 164, 35-42. [CrossRef]

25. Cobleigh, M.A.; Tabesh, B.; Bitterman, P.; Baker, J.; Cronin, M.; Liu, M.L.; Borchik, R.; Mosquera, J.M.; Walker, M.G.; Shak, S. Tumor gene expression and prognosis in breast cancer patients with 10 or more positive lymph nodes. Clin. Cancer Res. 2005, 11, 8623-8631. [CrossRef] [PubMed]

26. Dowsett, M.; Cuzick, J.; Wale, C.; Forbes, J.; Mallon, E.A.; Salter, J.; Quinn, E.; Dunbier, A.; Baum, M.; Buzdar, A.; et al. Prediction of risk of distant recurrence using the 21-gene recurrence score in node-negative and node-positive postmenopausal patients with breast cancer treated with anastrozole or tamoxifen: A TransATAC study. J. Clin. Oncol. 2010, 28, 1829-1834. [CrossRef]

27. Sparano, J.A.; Gray, R.J.; Makower, D.F.; Pritchard, K.I.; Albain, K.S.; Hayes, D.F.; Geyer, C.E., Jr.; Dees, E.C.; Perez, E.A.; Olson, J.A., Jr.; et al. Prospective Validation of a 21-Gene Expression Assay in Breast Cancer. N. Engl. J. Med. 2015, 373, 2005-2014. [CrossRef]

28. Toi, M.; Iwata, H.; Yamanaka, T.; Masuda, N.; Ohno, S.; Nakamura, S.; Nakayama, T.; Kashiwaba, M.; Kamigaki, S.; Kuroi, K.; et al. Clinical significance of the 21-gene signature (Oncotype DX) in hormone receptor-positive early stage primary breast cancer in the Japanese population. Cancer 2010, 116, 3112-3118. [CrossRef]

29. Paik, S.; Tang, G.; Shak, S.; Kim, C.; Baker, J.; Kim, W.; Cronin, M.; Baehner, F.L.; Watson, D.; Bryant, J.; et al. Gene expression and benefit of chemotherapy in women with node-negative, estrogen receptor-positive breast cancer. J. Clin. Oncol. 2006, 24, 3726-3734. [CrossRef]

30. Cronin, M.; Sangli, C.; Liu, M.L.; Pho, M.; Dutta, D.; Nguyen, A.; Jeong, J.; Wu, J.; Langone, K.C.; Watson, D. Analytical validation of the Oncotype DX genomic diagnostic test for recurrence prognosis and therapeutic response prediction in node-negative, estrogen receptor-positive breast cancer. Clin. Chem. 2007, 53, 1084-1091. [CrossRef]

31. Barcenas, C.H.; Raghavendra, A.; Sinha, A.K.; Syed, M.P.; Hsu, L.; Patangan, M.G., Jr.; Chavez-MacGregor, M.; Shen, Y.; Hortobagyi, G.H.; Valero, V.; et al. Outcomes in patients with early-stage breast cancer who underwent a 21-gene expression assay. Cancer 2017, 123, 2422-2431. [CrossRef] [PubMed]

32. Stemmer, S.M.; Steiner, M.; Rizel, S.; Soussan-Gutman, L.; Ben-Baruch, N.; Bareket-Samish, A.; Geffen, D.B.; Nisenbaum, B.; Isaacs, K.; Fried, G.; et al. Clinical outcomes in patients with node-negative breast cancer treated based on the recurrence score results: Evidence from a large prospectively designed registry. NPJ Breast Cancer 2017, 3, 33. [CrossRef] [PubMed]

33. Fayanju, O.M.; Park, K.U.; Lucci, A. Molecular Genomic Testing for Breast Cancer: Utility for Surgeons. Ann. Surg. Oncol. 2018, 25, 512-519. [CrossRef] [PubMed] 
34. Solin, L.J.; Gray, R.; Baehner, F.L.; Butler, S.M.; Hughes, L.L.; Yoshizawa, C.; Cherbavaz, D.B.; Shak, S.; Page, D.L.; Sledge, G.W., Jr.; et al. A multigene expression assay to predict local recurrence risk for ductal carcinoma in situ of the breast. J. Natl. Cancer. Inst. 2013, 105, 701-710. [CrossRef] [PubMed]

35. Solin, L.J.; Gray, R.; Hughes, L.L.; Wood, W.C.; Lowen, M.A.; Badve, S.S.; Baehner, F.L.; Ingle, J.N.; Perez, E.A.; Recht, A.; et al. Surgical Excision Without Radiation for Ductal Carcinoma in Situ of the Breast: 12-Year Results From the ECOG-ACRIN E5194 Study. J. Clin. Oncol. 2015, 33, 3938-3944. [CrossRef] [PubMed]

36. Rakovitch, E.; Nofech-Mozes, S.; Narod, S.A.; Hanna, W.; Thiruchelvam, D.; Saskin, R.; Taylor, C.; Tuck, A.; Sengupta, S.; Elavathil, L.; et al. Can we select individuals with low risk ductal carcinoma in situ (DCIS)? A population-based outcomes analysis. Breast Cancer Res. Treat. 2013, 138, 581-590. [CrossRef] [PubMed]

37. Rakovitch, E.; Nofech-Mozes, S.; Hanna, W.; Baehner, F.L.; Saskin, R.; Butler, S.M.; Tuck, A.; Sengupta, S.; Elavathil, L.; Jani, P.A.; et al. A population-based validation study of the DCIS Score predicting recurrence risk in individuals treated by breast-conserving surgery alone. Breast Cancer Res. Treat. 2015, 152, 389-398. [CrossRef]

38. Hughes, L.L.; Wang, M.; Page, D.L.; Gray, R.; Solin, L.J.; Davidson, N.E.; Lowen, M.A.; Ingle, J.N.; Recht, A.; Wood, W.C. Local excision alone without irradiation for ductal carcinoma in situ of the breast: A trial of the Eastern Cooperative Oncology Group. J. Clin. Oncol. 2009, 27, 5319-5324. [CrossRef]

39. Acs, G.; Esposito, N.N.; Kiluk, J.; Loftus, L.; Laronga, C. A mitotically active, cellular tumor stroma and/or inflammatory cells associated with tumor cells may contribute to intermediate or high Oncotype DX Recurrence Scores in low-grade invasive breast carcinomas. Mod. Pathol. 2012, 25, 556-566. [CrossRef]

40. Acs, G.; Kiluk, J.; Loftus, L.; Laronga, C. Comparison of Oncotype DX and Mammostrat risk estimations and correlations with histologic tumor features in low-grade, estrogen receptor-positive invasive breast carcinomas. Mod. Pathol. 2013, 26, 1451-1460. [CrossRef]

41. Grimes, M.; Coad, J.; Oliviero, B. Comparison of Oncotype DX Recurrence Score and standard immunohistochemical prognostic markers (abstract). Mod. Pathol. 2007, 20, 33A.

42. Kittaneh, M.; Montero, A.J.; Gluck, S. Molecular profiling for breast cancer: A comprehensive review. Biomark. Cancer 2013, 5, 61-70. [CrossRef] [PubMed]

43. Mook, S.; Schmidt, M.K.; Viale, G.; Pruneri, G.; Eekhout, I.; Floore, A.; Glas, A.M.; Bogaerts, J.; Cardoso, F.; Piccart-Gebhart, M.J.; et al. The 70-gene prognosis-signature predicts disease outcome in breast cancer patients with 1-3 positive lymph nodes in an independent validation study. Breast Cancer Res. Treat. 2009, 116, 295-302. [CrossRef] [PubMed]

44. Van 't Veer, L.J.; Dai, H.; van de Vijver, M.J.; He, Y.D.; Hart, A.A.; Mao, M.; Peterse, H.L.; van der Kooy, K.; Marton, M.J.; Witteveen, A.T.; et al. Gene expression profiling predicts clinical outcome of breast cancer. Nature 2002, 415, 530-536. [CrossRef] [PubMed]

45. Glas, A.M.; Floore, A.; Delahaye, L.J.; Witteveen, A.T.; Pover, R.C.; Bakx, N.; Lahti-Domenici, J.S.; Bruinsma, T.J.; Warmoes, M.O.; Bernards, R.; et al. Converting a breast cancer microarray signature into a high-throughput diagnostic test. BMC Genomics 2006, 7, 278. [CrossRef] [PubMed]

46. Cardoso, F.; Piccart-Gebhart, M.; Veer, L.V.; Rutgers, E.; Consortium, T. The MINDACT trial: The first prospective clinical validation of a genomic tool. Mol. Oncol. 2007, 1, 246-251. [CrossRef] [PubMed]

47. Mook, S.; Veer, L.J.V.; Rutgers, E.J.; Piccart-Gebhart, M.J.; Cardoso, F. Individualization of therapy using Mammaprint: From development to the MINDACT Trial. Cancer Genomics Proteomics 2007, 4, 147-155. [PubMed]

48. Knauer, M.; Mook, S.; Rutgers, E.J.; Bender, R.A.; Hauptmann, M.; van de Vijver, M.J.; Koornstra, R.H.; Bueno-de-Mesquita, J.M.; Linn, S.C.; Van 't Veer, L.J. The predictive value of the 70-gene signature for adjuvant chemotherapy in early breast cancer. Breast Cancer Res. Treat. 2010, 120, 655-661. [CrossRef] [PubMed]

49. Drukker, C.A.; Bueno-de-Mesquita, J.M.; Retel, V.P.; van Harten, W.H.; van Tinteren, H.; Wesseling, J.; Roumen, R.M.; Knauer, M.; van 't Veer, L.J.; Sonke, G.S.; et al. A prospective evaluation of a breast cancer prognosis signature in the observational RASTER study. Int. J. Cancer 2013, 133, 929-936. [CrossRef] [PubMed]

50. Drukker, C.A.; van Tinteren, H.; Schmidt, M.K.; Rutgers, E.J.; Bernards, R.; van de Vijver, M.J.; Van't Veer, L.J. Long-term impact of the 70-gene signature on breast cancer outcome. Breast Cancer Res. Treat. 2014, 143, 587-592. [CrossRef] [PubMed] 
51. Cardoso, F.; van't Veer, L.J.; Bogaerts, J.; Slaets, L.; Viale, G.; Delaloge, S.; Pierga, J.Y.; Brain, E.; Causeret, S.; DeLorenzi, M.; et al. 70-Gene Signature as an Aid to Treatment Decisions in Early-Stage Breast Cancer. N. Engl. J. Med. 2016, 375, 717-729. [CrossRef] [PubMed]

52. Gluck, S.; de Snoo, F.; Peeters, J.; Stork-Sloots, L.; Somlo, G. Molecular subtyping of early-stage breast cancer identifies a group of patients who do not benefit from neoadjuvant chemotherapy. Breast Cancer Res. Treat. 2013, 139, 759-767. [CrossRef]

53. Geiss, G.K.; Bumgarner, R.E.; Birditt, B.; Dahl, T.; Dowidar, N.; Dunaway, D.L.; Fell, H.P.; Ferree, S.; George, R.D.; Grogan, T.; et al. Direct multiplexed measurement of gene expression with color-coded probe pairs. Nat. Biotechnol. 2008, 26, 317-325. [CrossRef] [PubMed]

54. Parker, J.S.; Mullins, M.; Cheang, M.C.; Leung, S.; Voduc, D.; Vickery, T.; Davies, S.; Fauron, C.; He, X.; $\mathrm{Hu}, \mathrm{Z}$.; et al. Supervised risk predictor of breast cancer based on intrinsic subtypes. J. Clin. Oncol. 2009, 27, 1160-1167. [CrossRef] [PubMed]

55. Bastien, R.R.; Rodriguez-Lescure, A.; Ebbert, M.T.; Prat, A.; Munarriz, B.; Rowe, L.; Miller, P.; Ruiz-Borrego, M.; Anderson, D.; Lyons, B.; et al. PAM50 breast cancer subtyping by RT-qPCR and concordance with standard clinical molecular markers. BMC Med. Genomics 2012, 5, 44. [CrossRef] [PubMed]

56. Filipits, M.; Nielsen, T.O.; Rudas, M.; Greil, R.; Stoger, H.; Jakesz, R.; Bago-Horvath, Z.; Dietze, O.; Regitnig, P.; Gruber-Rossipal, C.; et al. The PAM50 risk-of-recurrence score predicts risk for late distant recurrence after endocrine therapy in postmenopausal women with endocrine-responsive early breast cancer. Clin. Cancer Res. 2014, 20, 1298-1305. [CrossRef] [PubMed]

57. Park, J.L.; Park, S.M.; Kim, J.H.; Lee, H.C.; Lee, S.H.; Woo, K.M.; Kim, S.Y. Forensic Body Fluid Identification by Analysis of Multiple RNA Markers Using NanoString Technology. Genomics Inform. 2013, 11, 277-281. [CrossRef] [PubMed]

58. Dowsett, M.; Sestak, I.; Lopez-Knowles, E.; Sidhu, K.; Dunbier, A.K.; Cowens, J.W.; Ferree, S.; Storhoff, J.; Schaper, C.; Cuzick, J. Comparison of PAM50 risk of recurrence score with oncotype DX and IHC4 for predicting risk of distant recurrence after endocrine therapy. J. Clin. Oncol. 2013, 31, 2783-2790. [CrossRef]

59. Sestak, I.; Dowsett, M.; Zabaglo, L.; Lopez-Knowles, E.; Ferree, S.; Cowens, J.W.; Cuzick, J. Factors predicting late recurrence for estrogen receptor-positive breast cancer. J. Natl. Cancer Inst. 2013, 105, 1504-1511. [CrossRef]

60. Nielsen, T.; Wallden, B.; Schaper, C.; Ferree, S.; Liu, S.; Gao, D.; Barry, G.; Dowidar, N.; Maysuria, M.; Storhoff, J. Analytical validation of the PAM50-based Prosigna Breast Cancer Prognostic Gene Signature Assay and nCounter Analysis System using formalin-fixed paraffin-embedded breast tumor specimens. BMC Cancer 2014, 14, 177. [CrossRef]

61. Goncalves, R.; Bose, R. Using multigene tests to select treatment for early-stage breast cancer. J. Natl. Compr. Canc. Netw. 2013, 11, 174-182. [CrossRef]

62. Filipits, M.; Rudas, M.; Jakesz, R.; Dubsky, P.; Fitzal, F.; Singer, C.F.; Dietze, O.; Greil, R.; Jelen, A.; Sevelda, P.; et al. A new molecular predictor of distant recurrence in ER-positive, HER2-negative breast cancer adds independent information to conventional clinical risk factors. Clin. Cancer Res. 2011, 17, 6012-6020. [CrossRef]

63. Dubsky, P.; Brase, J.C.; Jakesz, R.; Rudas, M.; Singer, C.F.; Greil, R.; Dietze, O.; Luisser, I.; Klug, E.; Sedivy, R.; et al. The EndoPredict score provides prognostic information on late distant metastases in ER+/HER2- breast cancer patients. Br. J. Cancer 2013, 109, 2959-2964. [CrossRef] [PubMed]

64. Dubsky, P.; Filipits, M.; Jakesz, R.; Rudas, M.; Singer, C.F.; Greil, R.; Dietze, O.; Luisser, I.; Klug, E.; Sedivy, R.; et al. EndoPredict improves the prognostic classification derived from common clinical guidelines in ER-positive, HER2-negative early breast cancer. Ann. Oncol. 2013, 24, 640-647. [CrossRef] [PubMed]

65. Martin, M.; Brase, J.C.; Calvo, L.; Krappmann, K.; Ruiz-Borrego, M.; Fisch, K.; Ruiz, A.; Weber, K.E.; Munarriz, B.; Petry, C.; et al. Clinical validation of the EndoPredict test in node-positive, chemotherapy-treated ER+/HER2- breast cancer patients: Results from the GEICAM 9906 trial. Breast Cancer Res. 2014, 16, R38. [CrossRef]

66. Ma, X.J.; Salunga, R.; Dahiya, S.; Wang, W.; Carney, E.; Durbecq, V.; Harris, A.; Goss, P.; Sotiriou, C.; Erlander, M.; et al. A five-gene molecular grade index and HOXB13:IL17BR are complementary prognostic factors in early stage breast cancer. Clin. Cancer Res. 2008, 14, 2601-2608. [CrossRef] [PubMed] 
67. Sgroi, D.C.; Sestak, I.; Cuzick, J.; Zhang, Y.; Schnabel, C.A.; Schroeder, B.; Erlander, M.G.; Dunbier, A.; Sidhu, K.; Lopez-Knowles, E.; et al. Prediction of late distant recurrence in patients with oestrogen-receptor-positive breast cancer: A prospective comparison of the breast-cancer index (BCI) assay, 21-gene recurrence score, and IHC4 in the TransATAC study population. Lancet Oncol. 2013, 14, 1067-1076. [CrossRef]

68. Jerevall, P.L.; Ma, X.J.; Li, H.; Salunga, R.; Kesty, N.C.; Erlander, M.G.; Sgroi, D.C.; Holmlund, B.; Skoog, L.; Fornander, T.; et al. Prognostic utility of HOXB13:IL17BR and molecular grade index in early-stage breast cancer patients from the Stockholm trial. Br. J. Cancer 2011, 104, 1762-1769. [CrossRef]

69. Sgroi, D.C.; Carney, E.; Zarrella, E.; Steffel, L.; Binns, S.N.; Finkelstein, D.M.; Szymonifka, J.; Bhan, A.K.; Shepherd, L.E.; Zhang, Y.; et al. Prediction of late disease recurrence and extended adjuvant letrozole benefit by the HOXB13/IL17BR biomarker. J. Natl. Cancer Inst. 2013, 105, 1036-1042. [CrossRef]

70. Zhang, Y.; Schnabel, C.A.; Schroeder, B.E.; Jerevall, P.L.; Jankowitz, R.C.; Fornander, T.; Stal, O.; Brufsky, A.M.; Sgroi, D.; Erlander, M.G. Breast cancer index identifies early-stage estrogen receptor-positive breast cancer patients at risk for early- and late-distant recurrence. Clin. Cancer Res. 2013, 19, 4196-4205. [CrossRef]

71. Harris, L.N.; Ismaila, N.; McShane, L.M.; Andre, F.; Collyar, D.E.; Gonzalez-Angulo, A.M.; Hammond, E.H.; Kuderer, N.M.; Liu, M.C.; Mennel, R.G.; et al. Use of Biomarkers to Guide Decisions on Adjuvant Systemic Therapy for Women With Early-Stage Invasive Breast Cancer: American Society of Clinical Oncology Clinical Practice Guideline. J. Clin. Oncol. 2016, 34, 1134-1150. [CrossRef]

72. Sestak, I.; Buus, R.; Cuzick, J.; Dubsky, P.; Kronenwett, R.; Denkert, C.; Ferree, S.; Sgroi, D.; Schnabel, C.; Baehner, F.L.; et al. Comparison of the Performance of 6 Prognostic Signatures for Estrogen Receptor-Positive Breast Cancer: A Secondary Analysis of a Randomized Clinical Trial. JAMA Oncol. 2018, 4, 545-553. [CrossRef]

73. Guacci, A.; Cordella, A.; Rocco, T.; Giurato, G.; Nassa, G.; Rizzo, F.; Carlomagno, C.; Pepe, S.; Tarallo, R.; Weisz, A. Identification of a novel truncating mutation in PALB2 gene by a multigene sequencing panel for mutational screening of breast cancer risk-associated and related genes. J. Clin. Lab. Anal. 2018, 32, e22418. [CrossRef]

74. Heeke, A.L.; Pishvaian, M.J.; Lynce, F.; Xiu, J.; Brody, J.R.; Chen, W.J.; Baker, T.M.; Marshall, J.L.; Isaacs, C. Prevalence of Homologous Recombination-Related Gene Mutations Across Multiple Cancer Types. JCO Precis. Oncol. 2018, 2018, 1-13. [CrossRef]

75. Hodgson, D.R.; Dougherty, B.A.; Lai, Z.; Fielding, A.; Grinsted, L.; Spencer, S.; O'Connor, M.J.; Ho, T.W.; Robertson, J.D.; Lanchbury, J.S.; et al. Candidate biomarkers of PARP inhibitor sensitivity in ovarian cancer beyond the BRCA genes. Br. J. Cancer 2018, 119, 1401-1409. [CrossRef]

76. Sparano, J.A.; Gray, R.J.; Makower, D.F.; Pritchard, K.I.; Albain, K.S.; Hayes, D.F.; Geyer, C.E., Jr.; Dees, E.C.; Goetz, M.P.; Olson, J.A., Jr.; et al. Adjuvant Chemotherapy Guided by a 21-Gene Expression Assay in Breast Cancer. N. Engl. J. Med. 2018, 379, 111-121. [CrossRef]

77. Sparano, J.A.; Gray, R.J.; Ravdin, P.M.; Makower, D.F.; Pritchard, K.I.; Albain, K.S.; Hayes, D.F.; Geyer, C.E., Jr.; Dees, E.C.; Goetz, M.P.; et al. Clinical and Genomic Risk to Guide the Use of Adjuvant Therapy for Breast Cancer. N. Engl. J. Med. 2019, 380, 2395-2405. [CrossRef]

78. Baselga, J.; Im, S.A.; Iwata, H.; Cortes, J.; de Laurentiis, M.; Jiang, Z.; Arteaga, C.L.; Jonat, W.; Clemons, M.; Ito, Y.; et al. Buparlisib plus fulvestrant versus placebo plus fulvestrant in postmenopausal, hormone receptor-positive, HER2-negative, advanced breast cancer (BELLE-2): A randomised, double-blind, placebo-controlled, phase 3 trial. Lancet Oncol. 2017, 18, 904-916. [CrossRef]

79. Fribbens, C.; O’Leary, B.; Kilburn, L.; Hrebien, S.; Garcia-Murillas, I.; Beaney, M.; Cristofanilli, M.; Andre, F.; Loi, S.; Loibl, S.; et al. Plasma ESR1 Mutations and the Treatment of Estrogen Receptor-Positive Advanced Breast Cancer. J. Clin. Oncol. 2016, 34, 2961-2968. [CrossRef]

80. Rothe, F.; Silva, M.J.; Venet, D.; Campbell, C.; Bradburry, I.; Rouas, G.; de Azambuja, E.; Maetens, M.; Fumagalli, D.; Rodrik-Outmezguine, V.; et al. Circulating Tumor DNA in HER2-Amplified Breast Cancer: A Translational Research Substudy of the NeoALTTO Phase III Trial. Clin. Cancer Res. 2019, 25, 3581-3588. [CrossRef]

81. Murtaza, M.; Dawson, S.J.; Pogrebniak, K.; Rueda, O.M.; Provenzano, E.; Grant, J.; Chin, S.F.; Tsui, D.W.; Marass, F.; Gale, D.; et al. Multifocal clonal evolution characterized using circulating tumour DNA in a case of metastatic breast cancer. Nat. Commun. 2015, 6, 8760. [CrossRef] [PubMed] 
82. Chen, Y.H.; Hancock, B.A.; Solzak, J.P.; Brinza, D.; Scafe, C.; Miller, K.D.; Radovich, M. Next-generation sequencing of circulating tumor DNA to predict recurrence in triple-negative breast cancer patients with residual disease after neoadjuvant chemotherapy. NPJ Breast Cancer 2017, 3, 24. [CrossRef] [PubMed]

83. Sparano, J.; O’Neill, A.; Alpaugh, K.; Wolff, A.C.; Northfelt, D.W.; Dang, C.T.; Sledge, G.W.; Miller, K.D. Association of Circulating Tumor Cells with Late Recurrence of Estrogen Receptor-Positive Breast Cancer: A Secondary Analysis of a Randomized Clinical Trial. JAMA Oncol. 2018, 4, 1700-1706. [CrossRef] [PubMed]

84. Pantel, K.; Brakenhoff, R.H.; Brandt, B. Detection, clinical relevance and specific biological properties of disseminating tumour cells. Nat. Rev. Cancer 2008, 8, 329-340. [CrossRef] [PubMed]

85. Ferreira, M.M.; Ramani, V.C.; Jeffrey, S.S. Circulating tumor cell technologies. Mol. Oncol. 2016, 10, $374-394$. [CrossRef] [PubMed]

86. Bidard, F.C.; Proudhon, C.; Pierga, J.Y. Circulating tumor cells in breast cancer. Mol. Oncol. 2016, 10, 418-430. [CrossRef] [PubMed]

87. Cristofanilli, M.; Budd, G.T.; Ellis, M.J.; Stopeck, A.; Matera, J.; Miller, M.C.; Reuben, J.M.; Doyle, G.V.; Allard, W.J.; Terstappen, L.W.; et al. Circulating tumor cells, disease progression, and survival in metastatic breast cancer. N. Engl. J. Med. 2004, 351, 781-791. [CrossRef]

88. Smerage, J.B.; Barlow, W.E.; Hortobagyi, G.N.; Winer, E.P.; Leyland-Jones, B.; Srkalovic, G.; Tejwani, S.; Schott, A.F.; O'Rourke, M.A.; Lew, D.L.; et al. Circulating tumor cells and response to chemotherapy in metastatic breast cancer: SWOG S0500. J. Clin. Oncol. 2014, 32, 3483-3489. [CrossRef]

89. Budd, G.T.; Cristofanilli, M.; Ellis, M.J.; Stopeck, A.; Borden, E.; Miller, M.C.; Matera, J.; Repollet, M.; Doyle, G.V.; Terstappen, L.W.; et al. Circulating tumor cells versus imaging-predicting overall survival in metastatic breast cancer. Clin. Cancer Res. 2006, 12, 6403-6409. [CrossRef]

90. Lucci, A.; Hall, C.S.; Lodhi, A.K.; Bhattacharyya, A.; Anderson, A.E.; Xiao, L.; Bedrosian, I.; Kuerer, H.M.; Krishnamurthy, S. Circulating tumour cells in non-metastatic breast cancer: A prospective study. Lancet Oncol. 2012, 13, 688-695. [CrossRef]

91. Kowalik, A.; Kowalewska, M.; Gozdz, S. Current approaches for avoiding the limitations of circulating tumor cells detection methods-implications for diagnosis and treatment of patients with solid tumors. Transl. Res. 2017, 185, 58-84.e15. [CrossRef] [PubMed]

92. Alix-Panabieres, C.; Vendrell, J.P.; Pelle, O.; Rebillard, X.; Riethdorf, S.; Muller, V.; Fabbro, M.; Pantel, K. Detection and characterization of putative metastatic precursor cells in cancer patients. Clin. Chem. 2007, 53, 537-539. [CrossRef] [PubMed]

93. Alix-Panabieres, C. EPISPOT assay: Detection of viable DTCs/CTCs in solid tumor patients. Recent Results Cancer Res. 2012, 195, 69-76. [PubMed]

94. Ramirez, J.M.; Fehm, T.; Orsini, M.; Cayrefourcq, L.; Maudelonde, T.; Pantel, K.; Alix-Panabieres, C. Prognostic relevance of viable circulating tumor cells detected by EPISPOT in metastatic breast cancer patients. Clin. Chem. 2014, 60, 214-221. [CrossRef] [PubMed]

95. Kim, T.H.; Wang, Y.; Oliver, C.R.; Thamm, D.H.; Cooling, L.; Paoletti, C.; Smith, K.J.; Nagrath, S.; Hayes, D.F. A temporary indwelling intravascular aphaeretic system for in vivo enrichment of circulating tumor cells. Nat. Commun. 2019, 10, 1478. [CrossRef]

96. Ignatiadis, M.; Lee, M.; Jeffrey, S.S. Circulating Tumor Cells and Circulating Tumor DNA: Challenges and Opportunities on the Path to Clinical Utility. Clin. Cancer Res. 2015, 21, 4786-4800. [CrossRef]

97. Reese, D.E.; Henderson, M.C.; Silver, M.; Mulpuri, R.; Letsios, E.; Tran, Q.; Wolf, J.K. Breast density does not impact the ability of Videssa(R) Breast to detect breast cancer in women under age 50. PLoS ONE 2017, 12, e0186198. [CrossRef]

98. Lourenco, A.P.; Benson, K.L.; Henderson, M.C.; Silver, M.; Letsios, E.; Tran, Q.; Gordon, K.J.; Borman, S.; Corn, C.; Mulpuri, R.; et al. A Noninvasive Blood-based Combinatorial Proteomic Biomarker Assay to Detect Breast Cancer in Women Under the Age of 50 Years. Clin. Breast Cancer 2017, 17, 516-525.e6. [CrossRef]

99. Sauter, E.R. Reliable Biomarkers to Identify New and Recurrent Cancer. Eur. J. Breast Health 2017, 13, $162-167$. [CrossRef]

100. Van Poznak, C.; Harris, L.N.; Somerfield, M.R. Use of Biomarkers to Guide Decisions on Systemic Therapy for Women with Metastatic Breast Cancer: American Society of Clinical Oncology Clinical Practice Guideline. J. Oncol. Pract. 2015, 11, 514-516. [CrossRef]

101. Witwer, K.W. Circulating microRNA biomarker studies: Pitfalls and potential solutions. Clin. Chem. 2015, 61, 56-63. [CrossRef] [PubMed] 
102. Duffy, M.J.; Walsh, S.; McDermott, E.W.; Crown, J. Biomarkers in Breast Cancer: Where Are We and Where Are We Going? Adv. Clin. Chem. 2015, 71, 1-23. [PubMed]

103. Hamam, R.; Hamam, D.; Alsaleh, K.A.; Kassem, M.; Zaher, W.; Alfayez, M.; Aldahmash, A.; Alajez, N.M. Circulating microRNAs in breast cancer: Novel diagnostic and prognostic biomarkers. Cell Death Dis. 2017, 8, e3045. [CrossRef] [PubMed]

104. Barh, D. (Ed.) OMICS Approaches in Breast Cancer: Towards Next-Generation Diagnosis, Prognosis, and Therapy; Springer: New York, NY, USA, 2014.

105. Asiago, V.M.; Alvarado, L.Z.; Shanaiah, N.; Gowda, G.A.; Owusu-Sarfo, K.; Ballas, R.A.; Raftery, D. Early detection of recurrent breast cancer using metabolite profiling. Cancer Res. 2010, 70, 8309-8318. [CrossRef] [PubMed]

106. Giskeodegard, G.F.; Grinde, M.T.; Sitter, B.; Axelson, D.E.; Lundgren, S.; Fjosne, H.E.; Dahl, S.; Gribbestad, I.S.; Bathen, T.F. Multivariate modeling and prediction of breast cancer prognostic factors using MR metabolomics. J. Proteome Res. 2010, 9, 972-979. [CrossRef] [PubMed]

107. Hadi, N.I.; Jamal, Q.; Iqbal, A.; Shaikh, F.; Somroo, S.; Musharraf, S.G. Serum Metabolomic Profiles for Breast Cancer Diagnosis, Grading and Staging by Gas Chromatography-Mass Spectrometry. Sci. Rep. 2017, 7, 1715. [CrossRef] [PubMed]

108. Oakman, C.; Tenori, L.; Biganzoli, L.; Santarpia, L.; Cappadona, S.; Luchinat, C.; di Leo, A. Uncovering the metabolomic fingerprint of breast cancer. Int. J. Biochem. Cell Biol. 2011, 43, 1010-1020. [CrossRef] [PubMed]

109. Tenori, L.; Oakman, C.; Morris, P.G.; Gralka, E.; Turner, N.; Cappadona, S.; Fornier, M.; Hudis, C.; Norton, L.; Luchinat, C.; et al. Serum metabolomic profiles evaluated after surgery may identify patients with oestrogen receptor negative early breast cancer at increased risk of disease recurrence. Results from a retrospective study. Mol. Oncol. 2015, 9, 128-139. [CrossRef]

110. Wei, S.; Liu, L.; Zhang, J.; Bowers, J.; Gowda, G.A.; Seeger, H.; Fehm, T.; Neubauer, H.J.; Vogel, U.; Clare, S.E.; et al. Metabolomics approach for predicting response to neoadjuvant chemotherapy for breast cancer. Mol. Oncol. 2013, 7, 297-307. [CrossRef]

111. Hart, C.D.; Vignoli, A.; Tenori, L.; Uy, G.L.; van To, T.; Adebamowo, C.; Hossain, S.M.; Biganzoli, L.; Risi, E.; Love, R.R.; et al. Serum Metabolomic Profiles Identify ER-Positive Early Breast Cancer Patients at Increased Risk of Disease Recurrence in a Multicenter Population. Clin. Cancer Res. 2017, 23, 1422-1431. [CrossRef]

112. Helland, T.; Henne, N.; Bifulco, E.; Naume, B.; Borgen, E.; Kristensen, V.N.; Kvaloy, J.T.; Lash, T.L.; Alnaes, G.I.G.; van Schaik, R.H.; et al. Serum concentrations of active tamoxifen metabolites predict long-term survival in adjuvantly treated breast cancer patients. Breast Cancer Res. 2017, 19, 125. [CrossRef] [PubMed]

113. Spratlin, J.L.; Serkova, N.J.; Eckhardt, S.G. Clinical applications of metabolomics in oncology: A review. Clin. Cancer Res. 2009, 15, 431-440. [CrossRef] [PubMed]

114. Aaltomaa, S.; Lipponen, P.; Eskelinen, M.; Kosma, V.M.; Marin, S.; Alhava, E.; Syrjanen, K. Lymphocyte infiltrates as a prognostic variable in female breast cancer. Eur. J. Cancer 1992, 28A, 859-864. [CrossRef]

115. Adams, S.; Gray, R.J.; Demaria, S.; Goldstein, L.; Perez, E.A.; Shulman, L.N.; Martino, S.; Wang, M.; Jones, V.E.; Saphner, T.J.; et al. Prognostic value of tumor-infiltrating lymphocytes in triple-negative breast cancers from two phase III randomized adjuvant breast cancer trials: ECOG 2197 and ECOG 1199. J. Clin. Oncol. 2014, 32, 2959-2966. [CrossRef] [PubMed]

116. Dieci, M.V.; Mathieu, M.C.; Guarneri, V.; Conte, P.; Delaloge, S.; Andre, F.; Goubar, A. Prognostic and predictive value of tumor-infiltrating lymphocytes in two phase III randomized adjuvant breast cancer trials. Ann. Oncol. 2015, 26, 1698-1704. [CrossRef] [PubMed]

117. Salgado, R.; Denkert, C.; Campbell, C.; Savas, P.; Nuciforo, P.; Aura, C.; de Azambuja, E.; Eidtmann, H.; Ellis, C.E.; Baselga, J.; et al. Tumor-Infiltrating Lymphocytes and Associations With Pathological Complete Response and Event-Free Survival in HER2-Positive Early-Stage Breast Cancer Treated With Lapatinib and Trastuzumab: A Secondary Analysis of the NeoALTTO Trial. JAMA Oncol. 2015, 1, 448-454. [CrossRef] [PubMed]

118. Denkert, C.; Loibl, S.; Noske, A.; Roller, M.; Muller, B.M.; Komor, M.; Budczies, J.; Darb-Esfahani, S.; Kronenwett, R.; Hanusch, C.; et al. Tumor-associated lymphocytes as an independent predictor of response to neoadjuvant chemotherapy in breast cancer. J. Clin. Oncol. 2010, 28, 105-113. [CrossRef] 
119. Denkert, C.; von Minckwitz, G.; Brase, J.C.; Sinn, B.V.; Gade, S.; Kronenwett, R.; Pfitzner, B.M.; Salat, C.; Loi, S.; Schmitt, W.D.; et al. Tumor-infiltrating lymphocytes and response to neoadjuvant chemotherapy with or without carboplatin in human epidermal growth factor receptor 2-positive and triple-negative primary breast cancers. J. Clin. Oncol. 2015, 33, 983-991. [CrossRef]

120. Ibrahim, E.M.; Al-Foheidi, M.E.; Al-Mansour, M.M.; Kazkaz, G.A. The prognostic value of tumor-infiltrating lymphocytes in triple-negative breast cancer: A meta-analysis. Breast Cancer Res. Treat. 2014, 148, 467-476. [CrossRef]

121. Issa-Nummer, Y.; Darb-Esfahani, S.; Loibl, S.; Kunz, G.; Nekljudova, V.; Schrader, I.; Sinn, B.V.; Ulmer, H.U.; Kronenwett, R.; Just, M.; et al. Prospective validation of immunological infiltrate for prediction of response to neoadjuvant chemotherapy in HER2-negative breast cancer-A substudy of the neoadjuvant GeparQuinto trial. PLoS ONE 2013, 8, e79775. [CrossRef]

122. Loi, S.; Michiels, S.; Salgado, R.; Sirtaine, N.; Jose, V.; Fumagalli, D.; Kellokumpu-Lehtinen, P.L.; Bono, P.; Kataja, V.; Desmedt, C.; et al. Tumor infiltrating lymphocytes are prognostic in triple negative breast cancer and predictive for trastuzumab benefit in early breast cancer: Results from the FinHER trial. Ann. Oncol. 2014, 25, 1544-1550. [CrossRef] [PubMed]

123. Loi, S.; Sirtaine, N.; Piette, F.; Salgado, R.; Viale, G.; van Eenoo, F.; Rouas, G.; Francis, P.; Crown, J.P.; Hitre, E.; et al. Prognostic and predictive value of tumor-infiltrating lymphocytes in a phase III randomized adjuvant breast cancer trial in node-positive breast cancer comparing the addition of docetaxel to doxorubicin with doxorubicin-based chemotherapy: BIG 02-98. J. Clin. Oncol. 2013, 31, 860-867. [CrossRef] [PubMed]

124. Mahmoud, S.M.; Paish, E.C.; Powe, D.G.; Macmillan, R.D.; Grainge, M.J.; Lee, A.H.; Ellis, I.O.; Green, A.R. Tumor-infiltrating CD8+ lymphocytes predict clinical outcome in breast cancer. J. Clin. Oncol. 2011, 29, 1949-1955. [CrossRef] [PubMed]

125. Mao, Y.; Qu, Q.; Zhang, Y.; Liu, J.; Chen, X.; Shen, K. The value of tumor infiltrating lymphocytes (TILs) for predicting response to neoadjuvant chemotherapy in breast cancer: A systematic review and meta-analysis. PLoS ONE 2014, 9, e115103. [CrossRef] [PubMed]

126. Menard, S.; Tomasic, G.; Casalini, P.; Balsari, A.; Pilotti, S.; Cascinelli, N.; Salvadori, B.; Colnaghi, M.I.; Rilke, F. Lymphoid infiltration as a prognostic variable for early-onset breast carcinomas. Clin. Cancer Res. 1997, 3 , 817-819. [PubMed]

127. Mohammed, Z.M.; Going, J.J.; Edwards, J.; Elsberger, B.; Doughty, J.C.; McMillan, D.C. The relationship between components of tumour inflammatory cell infiltrate and clinicopathological factors and survival in patients with primary operable invasive ductal breast cancer. Br. J. Cancer 2012, 107, 864-873. [CrossRef] [PubMed]

128. Salgado, R.; Denkert, C.; Demaria, S.; Sirtaine, N.; Klauschen, F.; Pruneri, G.; Wienert, S.; van den Eynden, G.; Baehner, F.L.; Penault-Llorca, F.; et al. The evaluation of tumor-infiltrating lymphocytes (TILs) in breast cancer: Recommendations by an International TILs Working Group 2014. Ann. Oncol. 2015, 26, 259-271. [CrossRef] [PubMed]

129. Hida, A.I.; Sagara, Y.; Yotsumoto, D.; Kanemitsu, S.; Kawano, J.; Baba, S.; Rai, Y.; Oshiro, Y.; Aogi, K.; Sagara, Y.; et al. Prognostic and predictive impacts of tumor-infiltrating lymphocytes differ between Triple-negative and HER2-positive breast cancers treated with standard systemic therapies. Breast Cancer Res. Treat. 2016, 158, 1-9. [CrossRef]

130. Gnant, M.; Harbeck, N.; Thomssen, C. Gallen/Vienna 2017: A Brief Summary of the Consensus Discussion about Escalation and De-Escalation of Primary Breast Cancer Treatment. Breast Care 2017, 12, 102-107. [CrossRef]

131. Kurozumi, S.; Inoue, K.; Matsumoto, H.; Fujii, T.; Horiguchi, J.; Oyama, T.; Kurosumi, M.; Shirabe, K. Prognostic utility of tumor-infiltrating lymphocytes in residual tumor after neoadjuvant chemotherapy with trastuzumab for HER2-positive breast cancer. Sci. Rep. 2019, 9, 1583. [CrossRef]

132. Mao, Y.; Qu, Q.; Chen, X.; Huang, O.; Wu, J.; Shen, K. The Prognostic Value of Tumor-Infiltrating Lymphocytes in Breast Cancer: A Systematic Review and Meta-Analysis. PLoS ONE 2016, 11, e0152500. [CrossRef] [PubMed]

133. Schumacher, T.N.; Schreiber, R.D. Neoantigens in cancer immunotherapy. Science 2015, 348, 69-74. [CrossRef] [PubMed] 
134. Snyder, A.; Makarov, V.; Merghoub, T.; Yuan, J.; Zaretsky, J.M.; Desrichard, A.; Walsh, L.A.; Postow, M.A.; Wong, P.; Ho, T.S.; et al. Genetic basis for clinical response to CTLA-4 blockade in melanoma. N. Engl. J. Med. 2014, 371, 2189-2199. [CrossRef] [PubMed]

135. Turk, J.L. Rudolf Virchow_Father of cellular pathology. J. R. Soc. Med. 1993, 86, 688-689. [PubMed]

136. Dong, F.; Irshad, H.; Oh, E.Y.; Lerwill, M.F.; Brachtel, E.F.; Jones, N.C.; Knoblauch, N.W.; Montaser-Kouhsari, L.; Johnson, N.B.; Rao, L.K.; et al. Computational pathology to discriminate benign from malignant intraductal proliferations of the breast. PLOS ONE 2014, 9, e114885. [CrossRef] [PubMed]

137. Janowczyk, A.; Madabhushi, A. Deep learning for digital pathology image analysis: A comprehensive tutorial with selected use cases. J. Pathol. Inform. 2016, 7, 29. [CrossRef] [PubMed]

138. Litjens, G.; Sanchez, C.I.; Timofeeva, N.; Hermsen, M.; Nagtegaal, I.; Kovacs, I.; Hulsbergen-Van de Kaa, C.; Bult, P.; van Ginneken, B.; van der Laak, J. Deep learning as a tool for increased accuracy and efficiency of histopathological diagnosis. Sci. Rep. 2016, 6, 26286. [CrossRef] [PubMed]

139. Madabhushi, A.; Lee, G. Image analysis and machine learning in digital pathology: Challenges and opportunities. Med. Image Anal. 2016, 33, 170-175. [CrossRef]

140. Ehteshami Bejnordi, B.; Veta, M.; van Diest, P.J.; van Ginneken, B.; Karssemeijer, N.; Litjens, G.; van der Laak, J.; the, C.C.; Hermsen, M.; Manson, Q.F.; et al. Diagnostic Assessment of Deep Learning Algorithms for Detection of Lymph Node Metastases in Women With Breast Cancer. JAMA 2017, 318, 2199-2210. [CrossRef]

141. Bejnordi, B.E.; Zuidhof, G.; Balkenhol, M.; Hermsen, M.; Bult, P.; van Ginneken, B.; Karssemeijer, N.; Litjens, G.; van der Laak, J. Context-aware stacked convolutional neural networks for classification of breast carcinomas in whole-slide histopathology images. J. Med. Imaging 2017, 4, 044504. [CrossRef]

142. Klimov, S.; Miligy, I.M.; Gertych, A.; Jiang, Y.; Toss, M.S.; Rida, P.; Ellis, I.O.; Green, A.; Krishnamurti, U.; Rakha, E.A.; et al. A whole slide image-based machine learning approach to predict ductal carcinoma in situ (DCIS) recurrence risk. Breast Cancer Res. 2019, 21, 83. [CrossRef] [PubMed]

143. Liu, Y.; Gadepalli, K.; Norouzi, M.; Dahl, G.E.; Kohlberger, T.; Boyko, A.; Venugopalan, S.; Timofeev, A.; Nelson, P.Q.; Corrado, G.S.; et al. Detecting cancer metastases on gigapixel pathology images. arXiv 2017, arXiv:1703.02442.

144. Djuric, U.; Zadeh, G.; Aldape, K.; Diamandis, P. Precision histology: How deep learning is poised to revitalize histomorphology for personalized cancer care. NPJ Precis. Oncol. 2017, 1, 22. [CrossRef] [PubMed]

145. Pannu, V.; Mittal, K.; Cantuaria, G.; Reid, M.D.; Li, X.; Donthamsetty, S.; McBride, M.; Klimov, S.; Osan, R.; Gupta, M.V.; et al. Rampant centrosome amplification underlies more aggressive disease course of triple negative breast cancers. Oncotarget 2015, 6, 10487-10497. [CrossRef] [PubMed]

146. Denu, R.A.; Zasadil, L.M.; Kanugh, C.; Laffin, J.; Weaver, B.A.; Burkard, M.E. Centrosome amplification induces high grade features and is prognostic of worse outcomes in breast cancer. BMC Cancer 2016, 16, 47. [CrossRef] [PubMed]

147. Mittal, K.; Kaur, J.; Wei, G.; Toss, M.S.; Osan, R.M.; Janssen, E.A.; Søiland, H.; Rakha, E.A.; Rida, P.C.; Aneja, R. A quantitative centrosomal amplification score (CAS) predicts local recurrence in ductal carcinoma in situ. In Proceedings of the 2018 San Antonio Breast Cancer Symposium, San Antonio, TX, USA, 4-8 December 2018. Abstract P5-18-02. [CrossRef]

148. Ogden, A.; Rida, P.C.; Aneja, R. Prognostic value of CA20, a score based on centrosome amplification-associated genes, in breast tumors. Sci. Rep. 2017, 7, 262. [CrossRef] [PubMed]

149. De Almeida, B.P.; Vieira, A.F.; Paredes, J.; Bettencourt-Dias, M.; Barbosa-Morais, N.L. Pan-cancer association of a centrosome amplification gene expression signature with genomic alterations and clinical outcome. PLoS Comput. Biol. 2019, 15, e1006832. [CrossRef]

150. Mittendorf, E.A.; Vila, J.; Tucker, S.L.; Chavez-MacGregor, M.; Smith, B.D.; Symmans, W.F.; Sahin, A.A.; Hortobagyi, G.N.; Hunt, K.K. The Neo-Bioscore Update for Staging Breast Cancer Treated with Neoadjuvant Chemotherapy: Incorporation of Prognostic Biologic Factors into Staging After Treatment. JAMA Oncol. 2016, 2, 929-936. [CrossRef]

151. Friedman, A.A.; Letai, A.; Fisher, D.E.; Flaherty, K.T. Precision medicine for cancer with next-generation functional diagnostics. Nat. Rev. Cancer 2015, 15, 747-756. [CrossRef]

152. Ridky, T.W.; Chow, J.M.; Wong, D.J.; Khavari, P.A. Invasive three-dimensional organotypic neoplasia from multiple normal human epithelia. Nat. Med. 2010, 16, 1450-1455. [CrossRef]

153. Sachs, N.; Clevers, H. Organoid cultures for the analysis of cancer phenotypes. Curr. Opin. Genet. Dev. 2014, 24, 68-73. [CrossRef] [PubMed] 
154. Sato, T.; Stange, D.E.; Ferrante, M.; Vries, R.G.; van Es, J.H.; van den Brink, S.; van Houdt, W.J.; Pronk, A.; van Gorp, J.; Siersema, P.D.; et al. Long-term expansion of epithelial organoids from human colon, adenoma, adenocarcinoma, and Barrett's epithelium. Gastroenterology 2011, 141, 1762-1772. [CrossRef] [PubMed]

155. Siolas, D.; Hannon, G.J. Patient-derived tumor xenografts: Transforming clinical samples into mouse models. Cancer Res. 2013, 73, 5315-5319. [CrossRef] [PubMed]

156. Jonas, O.; Landry, H.M.; Fuller, J.E.; Santini, J.T., Jr.; Baselga, J.; Tepper, R.I.; Cima, M.J.; Langer, R. An implantable microdevice to perform high-throughput in vivo drug sensitivity testing in tumors. Sci. Transl. Med. 2015, 7, 284ra57. [CrossRef] [PubMed]

157. Klinghoffer, R.A.; Bahrami, S.B.; Hatton, B.A.; Frazier, J.P.; Moreno-Gonzalez, A.; Strand, A.D.; Kerwin, W.S.; Casalini, J.R.; Thirstrup, D.J.; You, S.; et al. A technology platform to assess multiple cancer agents simultaneously within a patient's tumor. Sci. Transl. Med. 2015, 7, 284ra58. [CrossRef] [PubMed]

C 2019 by the authors. Licensee MDPI, Basel, Switzerland. This article is an open access article distributed under the terms and conditions of the Creative Commons Attribution (CC BY) license (http://creativecommons.org/licenses/by/4.0/). 